\title{
Deconstructing Pancreas Developmental Biology
}

\author{
Cecil M. Benitez ${ }^{1,4}$, William R. Goodyer ${ }^{1,4}$, and Seung K. Kim²,2,3 \\ ${ }^{1}$ Department of Developmental Biology, Stanford University School of Medicine, Stanford, California 94305-5329 \\ ${ }^{2}$ Department of Medicine (Oncology Division), Stanford University School of Medicine, Stanford, California \\ 94305-5329 \\ ${ }^{3}$ Howard Hughes Medical Institute, Stanford University School of Medicine, Stanford, California 94305-5329 \\ Correspondence: seungkim@stanford.edu
}

\section{SUMMARY}

The relentless nature and increasing prevalence of human pancreatic diseases, in particular, diabetes mellitus and adenocarcinoma, has motivated further understanding of pancreas organogenesis. The pancreas is a multifunctional organ whose epithelial cells govern a diversity of physiologically vital endocrine and exocrine functions. The mechanisms governing the birth, differentiation, morphogenesis, growth, maturation, and maintenance of the endocrine and exocrine components in the pancreas have been discovered recently with increasing tempo. This includes recent studies unveiling mechanisms permitting unexpected flexibility in the developmental potential of immature and mature pancreatic cell subsets, including the ability to interconvert fates. In this article, we describe how classical cell biology, genetic analysis, lineage tracing, and embryological investigations are being complemented by powerful modern methods including epigenetic analysis, time-lapse imaging, and flow cytometrybased cell purification to dissect fundamental processes of pancreas development.

\section{Outline}

1 Introduction

2 Initiation of pancreas development

3 Exocrine pancreas development

4 Endocrine pancreas development

5 Islet $\alpha$-cell development
6 Islet $\beta$-cell development

$7 \beta$-Cell dense core granule biogenesis

8 Concluding remarks

References

\footnotetext{
${ }^{4}$ These authors contributed equally.

Editors: Patrick P.L. Tam, W. James Nelson, and Janet Rossant

Additional Perspectives on Mammalian Development available at www.cshperspectives.org

Copyright (C 2012 Cold Spring Harbor Laboratory Press; all rights reserved; doi: 10.1101/cshperspect.a012401

Cite this article as Cold Spring Harb Perspect Biol 2012;4:a012401
} 


\section{INTRODUCTION}

Within the past two decades, there has been tremendous growth in our understanding of pancreas developmental biology (see the influential reviews by Pictet et al. 1972 and Slack 1995 for historical context). The considerable expansion of this field has been driven by incisive use of modern approaches to molecular embryology, cell lineage analysis, genetic network and signaling pathway analysis, and epigenetics, areas ably assessed in recent reviews and monographs (Oliver-Krasinski and Stoffers 2008; Gittes 2009; Pan and Wright 2011). Recently there has also been growing, ineluctable evidence of flexibility in fate decisions by pancreatic cells once thought "terminally differentiated," including conversion of non- $\beta$ cells to fates resembling $\beta$ cells (Puri and Hebrok 2010). Among visceral organs, the developmental biology of the pancreas has emerged as among the best understood, although much remains to be discovered, especially with respect to human pancreas development (McKnight et al. 2010). This intensive effort is driven, in part, by the devastating nature of pancreatic diseases, principally endocrine disorders like diabetes mellitus and exocrine disorders like pancreatic adenocarcinoma and pancreatitis. In our view, a more integrated picture of pancreas development has emerged, providing, for example, insights into timely subjects like islet $\beta$-cell biology through consideration of the developmental biology of non- $\beta$ cells, nonislet cells, and nonepithelial pancreatic cell populations.

Here, we review fundamental aspects of pancreas developmental biology, while providing focused analysis of emerging areas that deserve attention. This includes fetal development of pancreatic exocrine cells, islet $\alpha$ cells, $\beta$ cells, and $\beta$-cell maturation with a focus on organelle development. Other aspects of pancreas development, including definitive endoderm development, early pancreas induction, genetics of islet cell differentiation, intrinsic and extrinsic regulators of islet $\beta$-cell proliferation, and pancreas development in nonmammalian systems like zebrafish have been expertly reviewed elsewhere (Heit et al. 2006b; Zaret and Grompe 2008; Kinkel and Prince 2009; Tremblay 2010; Seymour and Sander 2011). Here we focus on studies from rodents, principally mice, which form the main basis of our understanding of pancreas developmental biology.

\section{INITIATION OF PANCREAS DEVELOPMENT}

Mouse pancreas development is operationally framed by three major periods: a primary transition from embryonic day (E) 9.5 to E12.5, a secondary transition from E12.5 to birth, and the postnatal period from birth to weaning (coinciding with the onset of adolescence). During the primary transition, pancreas development begins with thickening of the endoderm, proliferation of pancreatic progenitors, and evagination of a dorsal and ventral pancreatic bud at E9.5 and E9.75, respectively (panel 1 of Fig. 1) (see reviews by Jorgensen et al. 2007; Zaret and Grompe 2008). During bud evagination, transient epithelial stratification results in formation of microlumens, which subsequently coalesce and form continuous tubular structures characteristic of pancreas morphology (panels 2 and 3 of Fig. 1) (Villasenor et al. 2010). Although the molecular and cellular processes of tubulogenesis require further elucidation, elegant studies from Semb and colleagues suggest that Rho-GTPase family member Cdc42 may contribute to establishing tube formation given that in the absence of Cdc42, microlumens fail to coalesce into tubular structures (Kesavan et al. 2009). How Cdc42 coordinates tubule formation and other factors that contribute to tubulogenesis and microlumen formation represents an active and exciting area of research.

Coincident with tubulogenesis, specification and patterning of pancreatic progenitors results in formation of a bipotent stalk or "trunk" domain and multipotent "tip" domain (panel 3 of Fig. 1). Cells residing at the tip, or most distal area of a branch, are thought to include multipotent progenitor cells (MPCs) that give rise to both endocrine and exocrine cells, whereas progeny of cells residing in the trunk produce duct and endocrine cells (panel 3 of Fig. 1). After the primary transition, tip progenitors lose their multipotency and become preacinar cells at about E13 (panel 4 of Fig. 1; also see the following section). Cell-fate specification and pancreatic morphogenesis are intricately coordinated by cell-cell interactions and extrinsic signals emanated from nonpancreatic tissues, such as mesenchyme and blood vessels (Puri and Hebrok 2010; Magenheim et al. 2011). The coordination of extrinsic signals and cell intrinsic mechanisms of transcriptional and chromatin regulation in the specification of cell fate is an area of intensive exploration (for example, see Xu et al. 2011).

\section{EXOCRINE PANCREAS DEVELOPMENT}

The exocrine compartment constitutes nearly 95\% of pancreatic mass and is composed of two major cell types: acinar and duct cells. Acini secrete digestive enzymes, such as amylase, that are channeled into the duodenum through a branched network of duct cells. Development of acinar and duct cells is intertwined with tubulogenesis and branching morphogenesis (Hick et al. 2009; Kesavan et al. 2009; Villasenor et al. 2010), but the cell interactions and mechanisms coordinating morphogenesis with acinar and ductal cell-fate specification are not well understood. Here, we focus on the transcriptional cascades that influence 


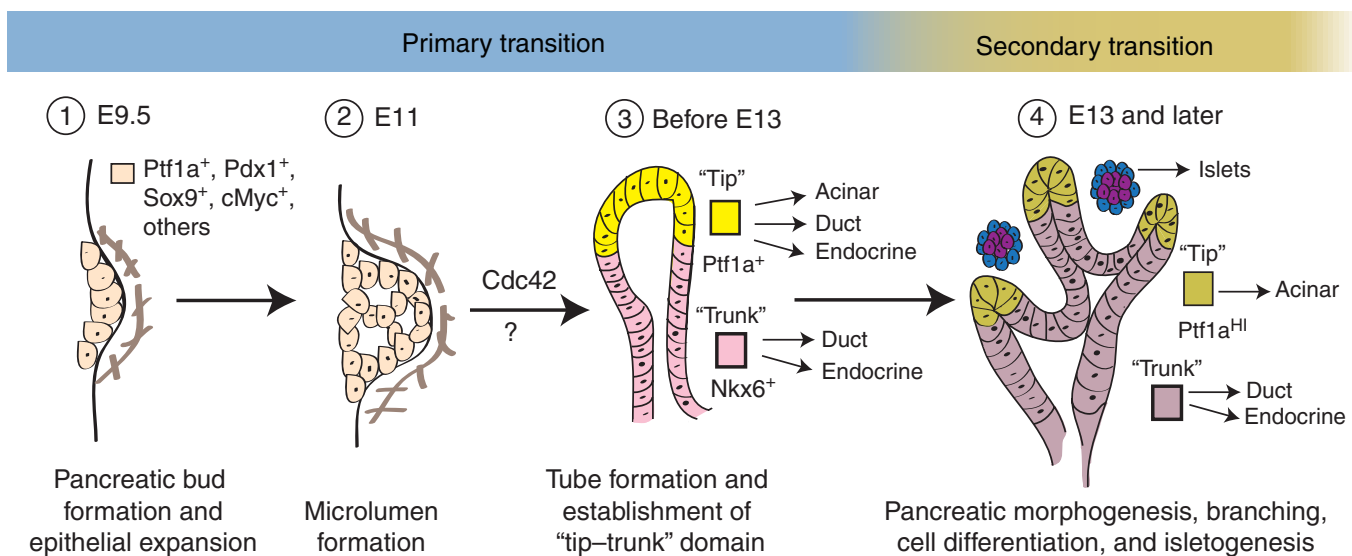

Figure 1. Pancreatic morphogenesis and developmental regulation. Mouse pancreatic development is characterized by a "primary transition" from embryonic day (E) 9.5 to E12.5 and a "secondary transition" from E13 to birth. (Panel 1) Pancreatic budding and pancreatic proliferation occur at approximately E9.5 and a subset of epithelial cells at that stage express pancreas-specific transcription factor 1a (Ptfla), pancreatic and duodenal homeobox 1 (Pdx1), sry-box 9 (Sox9), cMyc, and other transcription factors. (Panel 2) Proliferation of epithelial cells results in the formation of microlumens (empty white spaces) at E11. Mesenchymal cells (brown crosshatch) overlie the developing pancreatic bud and secrete a variety of growth and differentiation factors (see text). Before E13, Cdc42 influences microtubule coalescence and formation of a continuous branched tube. (Panel 3) Coincident with tubulogenesis, multipotent "tip" and bipotent "trunk" domains establish. The multipotent Ptf1a ${ }^{+}$tip progenitors derive acinar, duct, and endocrine cells, whereas the bipotent $N k x 6$ homeobox $\left(\mathrm{Nkx}^{+}\right)$trunk progenitors produce duct and endocrine cells. (Panel 4) After E13 and during the secondary transition, pancreatic branching, cell differentiation, acinar cell expansion, and islet formation drive pancreatic morphogenesis. Islets represent clusters of endocrine cells. At this stage, the "tip" domain will derive acinar cells, whereas the "trunk" domain will derive duct and endocrine cells.

acinar cell-fate lineage allocation and duct cell biology (MacDonald et al. 2010).

\subsection{Acinar Specification}

Acinar cells derive from multipotent progenitors that express Ptfla, a basic helix-loop-helix (bHLH) transcription factor initially expressed in pancreatic progenitors and later maintained in acini (Krapp et al. 1998; Kawaguchi et al. 2002; Hald et al. 2008). Absence of Ptfla results in failure of acinar cell formation. Recent studies in zebrafish suggest that reduced Ptfla expression permits endocrine allocation, whereas increased Ptfla expression commits pancreatic progenitors to an acinar fate (Zhou et al. 2007; Dong et al. 2008; Hesselson et al. 2011). Thus, Ptf1a may have dual roles, dependent on its expression levels or activity. Mice permitting temporal and conditional Ptfla inactivation or expression should yield further insight into acinar cell specification and development, and also to determine if levels of Ptfla expression can adjust the fate of multipotent progenitors.

Studies by Schaffer et al. (2010) show that the interaction between Ptfla and Nkx6 transcription factors contributes to developmental acinar cell allocation. The investigators suggest that a mutual inhibitory interaction between Ptfla and
Nkx6 operates during a competence window in MPCs before E14. In this model, Ptfla represses Nkx6 expression to promote acinar development, whereas Nkx6 factors like Nkx6.1 or Nkx6.2 repress Ptfla expression to promote duct or endocrine development (Fig. 2A). Because endocrine and duct cells are present in Nkx6.1/Nkx6.2 double mutants (Henseleit et al. 2005), it is likely that additional factors may repress acinar cell fate and drive endocrine and ductal development in MPCs. In vitro studies have shown that histone deacetylation also influences acinar cell fate (Haumaitre et al. 2008). Thus, further studies should reveal mechanistic connections between transcriptional and epigenetic regulation of acinar cell allocation from pancreatic MPCs.

Acinar development is also regulated by multiple extrinsic signals and cell-cell interactions. For example, pancreatic mesenchymal cells secrete FGF10 and follistatin, which promote acinar specification by activation and inhibition of the FGF and TGF $\beta$ signaling pathways, respectively (Miralles et al. 1998; Duvillie et al. 2006). In addition, other studies suggest Notch and Wnt signaling can repress acinar cell fate (Apelqvist et al. 1999; Miyamoto et al. 2003; Esni et al. 2004). In general, the link between signaling, transcriptional, and epigenetic control of acinar cell specification remains far less well understood than those involved in 
C.M. Benitez et al.

A

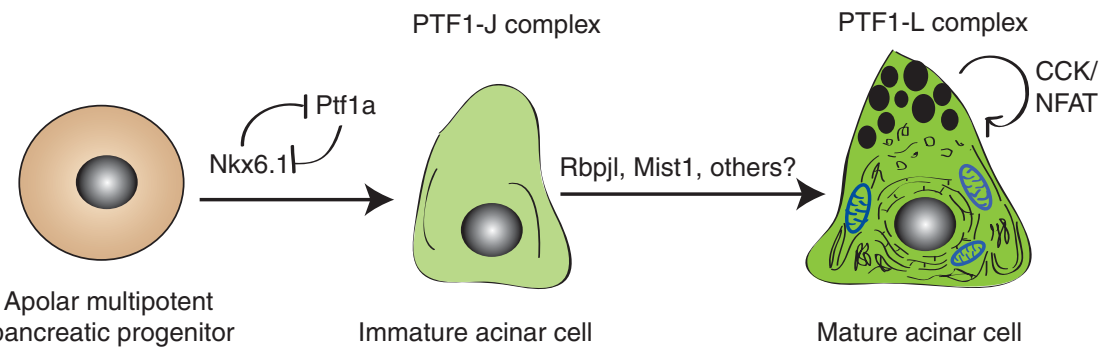

B

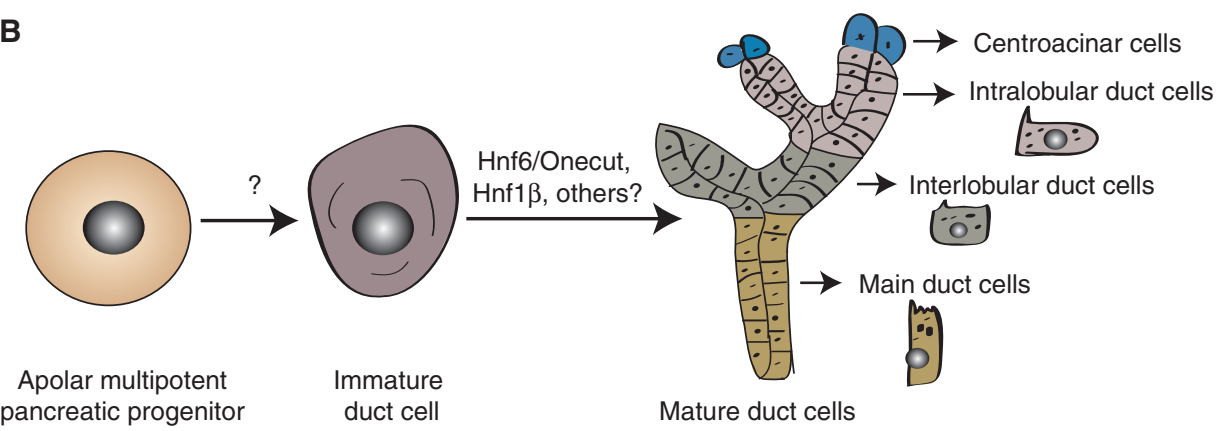

Figure 2. Pancreatic acinar and ductal cell differentiation. Apolar multipotent progenitors develop into three distinct progeny: acinar cells (top, green), duct cells (bottom, brown), and endocrine islet cells (not shown). (A) During acinar development expression of Ptfla represses $\mathrm{Nkx} 6$, thereby suppressing alternative duct and endocrine cell fates. The commitment of early acinar cells requires the formation of a Ptfla-Rbpj trimeric complex (PTF1-J). Acinar maturation requires formation of a Ptfla-Rbpjl trimeric complex (PTF1-L) and is dependent on muscle, intestine, and stomach expression 1 (Mist1) and recombination signal-binding protein for immunoglobulin kappa J regionlike (Rbpjl) and possibly other unknown factors. Maturation produces pyramidal polarized acinar cells with specialized organelles and high-secretory capacity. Cholecystokinin (CCK) and NFAT signaling influence adaptive growth of acinar cells. $(B)$ Duct cells derive from apolar progenitors that become polarized through unknown mechanisms and form primary cilia, an organelle whose development requires both hepatocyte nuclear factor 6 (Hnf6) and Hnf1 $\beta$. Duct cell heterogeneity within pancreatic branches is depicted (see text).

islet cell differentiation. For additional information on extrinsic factors that regulate acinar development see Puri and Hebrok (2010).

\subsection{Acinar Cell Maturation and Function}

Acinar cells are polarized pyramidal-shaped cells with high secretory capacity. To accommodate their secretory burden, acini have numerous mitochondria, unusually extensive Golgi and endoplasmic reticulum, and prominent electron-dense zymogen granules (Fig. 2A) (Pictet et al. 1972). Mist1, a bHLH transcription factor, has been implicated in regulating acinar cell polarity and exocytosis (Pin et al. 2001). Mist1 is postulated to regulate RAB26 and $\mathrm{RAB} 3 \mathrm{D}$ to control acinar exocrine granule maturation, similar to its role in stomach chief cells (Tian et al. 2010). Global profiling of adult pancreatic gene expression has recently enhanced our understanding of regulatory mechanisms controlling secretory functions in acinar cells (MacDonald et al. 2010; Dorrell et al. 2011b). This work suggests that the protein-protein interactions of PTF1 may be critical in driving acinar maturation and function. During the primary transition, PTF1 forms a trimeric complex with TCF12 and Rbpj (a complex called PTF1-J) (Beres et al. 2006; Masui et al. 2007) that is required for acinar cell development and function. As pancreatic progenitors commit to an acinar fate, Rbpj is replaced by Rbpjl within the PTF1 complex (termed PTF1-L) (Fig. 2A). Evidence suggests that this switch from PTF1-J to PTF1-L is crucial for the high-level expression of genes encoding hydrolytic enzymes, mitochondrial components, and exocytosis machinery-the hallmark components of functionally mature acini (Beres et al. 2006; Masui et al. 2007, 2010). Autoregulation of Ptfla and Rbpjl may ensure maximal secretory protein synthesis and mitochondrial metabolism, a feature that has also been postulated to reinforce or maintain acinar cell identity (Masui et al. 2008). In the future, identification of PTF1-L and Mist1 targets should reveal how these factors coordinately regulate acinar development. Conditional inactivation of Rbpjl and Rbpj during acinar 
maturation, as well as identification of additional PTF1-J and PTF1-L complex components, should further delineate the dynamic genetic and biochemical mechanisms governing establishment of acinar cell fate and function.

\subsection{Acinar Cell Growth, Regeneration, and Plasticity}

Acinar cells continue to differentiate, mature, and proliferate until weaning (Desai et al. 2007). Adult acinar cells, however, show a low basal proliferative index and appear to have poor regenerative capacity (Desai et al. 2007; Scott Swenson et al. 2009). Ptf1a and Mist1 are expressed in adult acini and recent studies show that both factors induce expression of the cell-cycle inhibitor Cdkn1a (p21) (Jia et al. 2008). Thus, expression of these transcription factors may contribute to the low proliferative index of adult acinar cells. In both experimental and physiological settings, however, acinar cells can adaptively expand. For example, growth occurs in response to a high protein diet, hyperphagia, pregnancy, and lactation. Recent studies reveal that one regulator of this postnatal facultative expansion is the hormone cholecystokinin (CCK) (Fig. 2A). An increase of endogenous CCK secretion can be induced by systemic administration of protease inhibitors, leading to pancreatic exocrine growth (Gurda et al. 2008). This acinar growth response to CCK stimulation may be dependent on calcineurin/NFAT signaling (Gurda et al. 2008, 2010). It will be interesting to assess if CCK affects other intrinsic growth regulators like Ptfla, Mist1, and p21. Genetic inactivation of $\beta$-catenin and c-Myc also results in acinar hypoplasia (Murtaugh et al. 2005; Murtaugh 2008; Nakhai et al. $2008 a, b)$, suggesting that both $\beta$-catenin and c-Myc enhance acinar cell proliferation and/or survival. Creation of new methods for conditional genetic gain- or loss-offunction studies in mouse acinar cells should help to dissect the signaling connections between growth factors and intrinsic factors like $\beta$-catenin and c-Myc.

Although the regenerative potential of acinar cells appears limited, recent studies suggest that acinar cells have the potential to produce nonacinar cell types in the pancreas. Blaine et al. (2010) showed that on overexpression of TGF $\alpha$, pancreatic acinar cells have the ability to transdifferentiate into hyperplastic duct cells, which are characteristic of both chronic pancreatitis and pancreatic adenocarcinoma in humans. In addition, Zhou et al. (2008) showed that acinar cells are responsive to cellular reprogramming. By expressing three key transcription factors in $\beta$-cell development (Ngn3, $P d x 1$, and MafA), they were able to reprogram acinar cells into cells that resembled $\beta$ cells. Whether all acinar cells are equally responsive to cellular reprogramming remains to be seen. Dorrell et al. (2011a) have identified different subsets of acinar cells based on cell surface marker expression. Gene-expression profiling of acinar cell subsets at various stages and under different injury conditions may further elucidate the molecular programs that influence acinar cell plasticity, regeneration, and function.

\subsection{Duct Cell Development and Biology}

Duct cells are ciliated, polarized epithelial cells that secrete bicarbonate, mucins, and form extensive networks of tubules that begin as centroacinar cells (thought by some to be modified ductal cells contiguous with acinar cells) (Fig. 2B). Although the potential of duct cells in regeneration of endocrine cells has sparked interest in ductal biology, the transcriptional programs that influence duct cell development and function are not well understood. Morphological and functional heterogeneity reflecting duct cell location has likely complicated attempts to understand duct cell development (Kopp et al. 2011). Columnar epithelia form the main ducts, whereas stratified squamous and simple squamous epithelia form the interlobular and intralobular ducts, respectively (Fig. 2B) (Githens 1988). The biological significance of this heterogeneity has not been determined and may be relevant to the understanding of duct celldependent diseases such as pancreatic adenocarcinoma, cystic fibrosis, and pancreatitis (Sharer et al. 1998; Morris et al. 2010; Braganza et al. 2011).

Advances in the biology of pancreatic ducts would be accelerated by identification of molecular markers of duct cell subsets at specific developmental stages. For example, unlike the marker Ptfla for acinar cell progenitors and Ngn3 for islet cell progenitors (see Sect. 4 below), markers (or regulators) of a ductal cell progenitor have not been identified. Thus, multiple fundamental questions about duct cell specification and allocation are ripe for study. For example, what distinguishes a bipotent trunk progenitor from a differentiating duct cell? What signaling pathways promote or inhibit ductal specification and differentiation? Recent studies suggest that formation of primary cilia, a subcellular signaling organelle in duct cells, requires the transcription factors Hnfl $\beta$ and Hnf6/Onecut 1 (Haumaitre et al. 2005; Zhang et al. 2009). In the absence of Hnf6, ductal cysts form and ductal cells lack a primary cilium (Pierreux et al. 2006; Zhang et al. 2009). Recently, the transcription factors Meis1/2 were shown to regulate ductal Krt19 expression (von Burstin et al. 2010). Although these studies suggest that Hnf6/Onecut1, Hnf1 $\beta$, and Meis factors regulate specific aspects of duct development, many genetic determinants of duct formation and maturation remain unknown. It seems likely that flow cytometry-based purification like that performed by Dorrell et al. (2011b) on 
subsets of human duct cells, or methods like laser-capture microdissection may shed light on embryonic pancreas duct development.

\subsection{Duct Cell Regeneration and Plasticity}

Compared to embryonic ductal cells, even less is known about the mechanisms regulating renewal, regeneration, and fate in adult ductal cells. Subsets of researchers have investigated the regenerative potential of ductal cells, with specific emphasis on ductal cell transdifferentiation into endocrine cells (Desgraz et al. 2011). Some investigations have reported regeneration of $\beta$ cells and other pancreatic cell types from duct or duct-associated cells (Inada et al. 2008; Xu et al. 2008; Furuyama et al. 2011), but some workers have questioned the principal conclusions from these studies, based on lineage tracing evidence (Solar et al. 2009). For example, some studies have suggested the possibility of adult human ductal cell conversion toward endocrine fates (Bonner-Weir et al. 2000), whereas other studies by Furuyama et al. (2011) suggest that adult duct cells can physiologically replenish acinar and duct cells but not endocrine cells during adulthood. The potential of adult duct cells to replenish nonduct cells is even more limited according to lineage tracing studies by Ferrer, Sander, and colleagues (Solar et al. 2009; Kopp et al. 2011). By lineage tracing the progeny of $\mathrm{Hnfl}^{+} \mathrm{\beta}^{+}$and Sox $9^{+}$adult duct cells, respectively, both groups concluded duct cells can produce endocrine and duct cells during embryogenesis but not after birth (Solar et al. 2009; Kopp et al. 2011). These discrepancies may reflect duct cell heterogeneity and differences in the cell labeling strategies used. Again, additional rigorous lineage tracing or cell purification are needed to verify these findings. For further information on some of the controversies surrounding duct cell regeneration and plasticity see Xia et al. (2009) and Kawaguchi et al. (2011).

It seems clear that the potential of duct cells to contribute to the neogenesis of endocrine cells may be stage dependent, but the question of adult duct cell plasticity in the setting of pancreatic injury deserves further investigation, especially because most pancreatic neoplasms are likely of ductal lineage. Further analysis of duct cell markers and molecular understanding of duct cell biology may yield diagnostic markers of this disease.

\section{ENDOCRINE PANCREAS DEVELOPMENT}

Mature pancreatic endocrine cells derive from a subset of epithelial cells that transiently express Neurogenin3 (Ngn3), delaminate from the epithelia, and aggregate in clusters called Islets of Langerhans (Fig. 3). Lineage tracing studies suggest that $\mathrm{Ngn}^{+}$endocrine progenitors are unipotent, postmitotic cells that engender separately five endocrine cell types: $\alpha, \beta, \delta, \mathrm{PP}$, and $\varepsilon$ cells (Fig. $4 \mathrm{~A}$ ) (Gu et al. 2002; Desgraz and Herrera 2009; Miyatsuka et al. 2011). However, the persistence of $\varepsilon$ cells in adult islets is not established. The birth of each endocrine cell type from $\mathrm{Ngn}^{+}$progenitors may be temporally regulated: in genetic complementation studies permitting controlled Ngn3 activation, Grapin-Botton and coworkers found evidence for sequential "competence" states in the pancreas that led to the birth of $\alpha$ cells first, then $\beta$ cells and $\delta$ cells, followed by PP cells (Johansson et al. 2007). The birth of $\varepsilon$ cells was not reported. Although these findings help frame our understanding of islet cell allocation, the basis of these postulated cell-intrinsic periods of competence has not yet been elucidated.

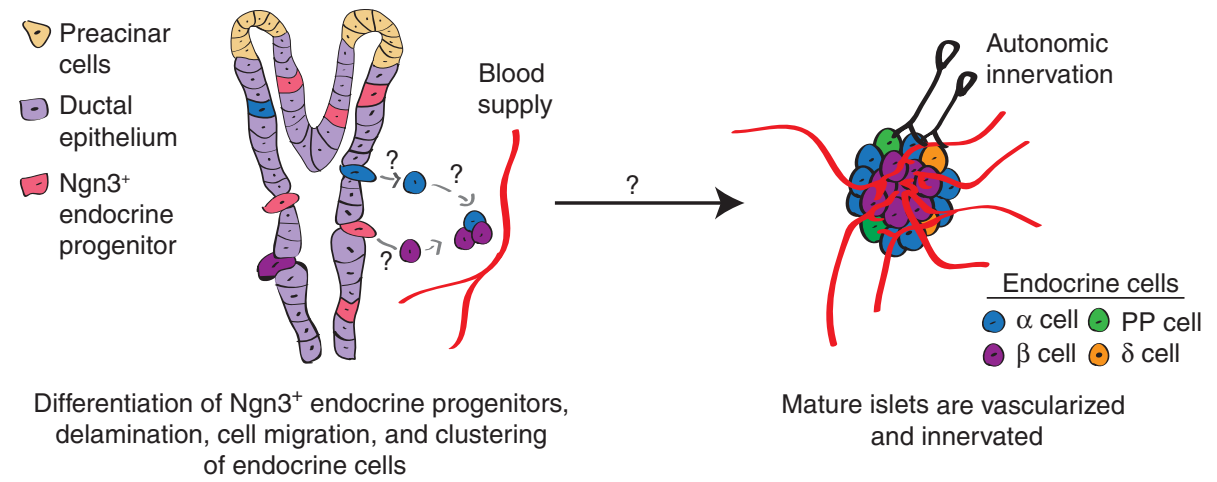

Figure 3. Events culminating in islet morphogenesis. Endocrine cells derive from unipotent Neurogenin3 $\left(\mathrm{Ngn} 3^{+}\right)$ endocrine progenitors (pink). On differentiation, endocrine cells delaminate from the ductal epithelia (light purple), migrate toward the mesenchyme (not shown), and aggregate into clusters called islets. For simplicity only $\alpha$ cells (blue) and $\beta$ cells (purple) are depicted delaminating from the ductal epithelia and migrating toward blood vessels (red). Coincident with islet morphogenesis, vascularization, and innervation of islets by the autonomic nervous system occurs (black). 
Recent work suggests that the threshold of Ngn3 expression may be important in committing pancreatic progenitors to the endocrine lineage (Wang et al. 2010). According to Wang et al. (2010), epithelial progenitors that fail to attain a specific threshold of Ngn3 expression default to a ductal or acinar fate. The ability of these failed endocrine progenitors to adopt a ductal or acinar fate may be stage dependent (Beucher et al. 2011). By lineage tracing failed endocrine progenitors at various stages, Gradwohl and colleagues determined that before E12.5, failed endocrine progenitors can differentiate into acinar or duct cells but after E12.5 they differentiate into duct cells and not acinar cells. This study supports previous findings by Zhou et al. (2007) suggesting that after the secondary transition endocrine progenitors arise from bipotent "trunk" progenitors committed to ductal and endocrine lineages, whereas early endocrine progenitors arise from multipotent progenitors (panel 3 of Fig. 1).

Although the levels of Ngn3 are important in triggering endocrine fate, how this occurs is not known. Some Ngn3 downstream factors that are critical for endocrine differentiation and development have been identified and include NeuroD1, IA2, Pax4, Arx, Rfx6 (Smith et al. 2010; Soyer et al. 2010), and others (summarized in Fig. 4A and reviewed by Rukstalis and Habener 2009; Seymour and Sander 2011). How these transcription factors might specify changes that contribute to allocation of specific islet cell subsets remains unclear. Moreover, it is not yet known if Ngn3 activity may also induce repressors of exocrine differentiation.

Based on loss-of-function analysis in mice, Ngn3 likely also regulates other crucial features of islet development, including epithelial delamination, cell migration, and cellcycle exit (Rukstalis and Habener 2007; Miyatsuka et al 2011). Elucidation of the basis for $\mathrm{Ngn}^{+}$progeny delamination and migration will likely benefit from development of videomicroscopy methods at a single cell resolution. Possible mechanisms regulating delamination include (1) asymmetric cell division or (2) epithelial-to-mesenchymal transition (EMT). Prior studies suggest EMT may be regulated in pancreatic cells by Snail2 (Rukstalis and Habener 2007), a zinc-finger protein known to regulate EMT in other tissues. Recently, German and colleagues have implicated Cdkn1a as a possible Ngn3 target that stimulates cell-cycle exit to restrict expansion of islet progenitors (Miyatsuka et al. 2011). As described below, $\beta$-cell progeny of $\mathrm{Ngn}^{+}$cells recover their ability to expand after the secondary transition, suggesting that $C d k n 1 a$ restriction of endocrine cell proliferation may be transient.

In mice, the stereotyped architecture of islets with insulin-expressing $\beta$ cells contiguous with non- $\beta$ cells is detected late in gestation by E18 (Fig. 3) (Herrera et al. 1991). Other evolutionarily conserved features of islet maturation include vascularization and innervation by the autonomic nervous system (ANS) (Fig. 3). Advances in our understanding of the basis of islet cell developmental interactions with vascular endothelial elements have been recently reviewed (Brissova et al. 2006; Eberhard and Lammert 2009). Here we focus on specific aspects of the development of islet $\alpha$ cells and $\beta$ cells.

\section{$5 \quad$ ISLET $\alpha$-CELL DEVELOPMENT}

Because of the primacy of insulin in mammals, the developmental biology of glucagon-producing $\alpha$ cells has received comparatively far less attention. However, several factors have led to intensified interest and investigations of $\alpha$-cell development, including discoveries about the role of $\alpha$ cells and glucagon in type 2 diabetes (reviewed in Edgerton and Cherrington 2011), the realization that a broader understanding of islet cell biology is needed to control development of replacement islets from multipotent cell sources, and the beguiling possibility of converting $\alpha$ cells into functional $\beta$ cells (Collombat et al. 2009; Thorel et al. 2010). Here we review aspects of $\alpha$-cell specification, differentiation, and maturation. For a more detailed review on $\alpha$-cell physiology and glucagon regulation please see Gromada et al. (2007) and Gosmain et al. (2011).

Genetic studies of $\alpha$-cell development have discovered various transcription factors that influence $\alpha$-cell development and maturation such as Pax6, MafB, Arx, and Foxa2 (Fig. 4A) (Gosmain et al. 2011). Pax6 mutants lack $\alpha$ cells, and have reduced glucagon expression and MafB expression, another regulator of glucagon expression that is selectively expressed in adult $\alpha$ cells in mice (Artner et al. 2006; Nishimura et al. 2006, 2008; Gosmain et al. 2010). Regulation of glucagon processing may also be regulated by Foxa2. Conditional knockout studies show that mutant $\alpha$ cells lacked the enzyme that processes proglucagon, and consequently had a $90 \%$ reduction of glucagon expression (Lee et al. 2005). Although these transcription factors affect some aspect of $\alpha$-cell fate and maturation, much like the $\beta$ cell (discussed below), we do not know the molecular mechanisms governing the maturation of $\alpha$ cells toward glucagon-secreting $\alpha$ cells.

Recently, there has been increased progress in our understanding of the mechanisms regulating $\alpha$-cell development and fate (reviewed by Bramswig and Kaestner 2011). Arx, a transcription factor expressed in $\alpha$ cells and PP cells, is required for $\alpha$-cell formation and maintenance of adult $\alpha$ cells. Arx null mutants reveal an early loss of mature $\alpha$ cells with a concomitant increase in $\beta$ cells and $\delta$ cells, whereas misexpression of Arx in $\beta$ cells promotes development of $\alpha$ cells and PP cells (Collombat et al. 2007). In mice with pancreas-specific loss of $A r x$, there is complete $\alpha$-cell 


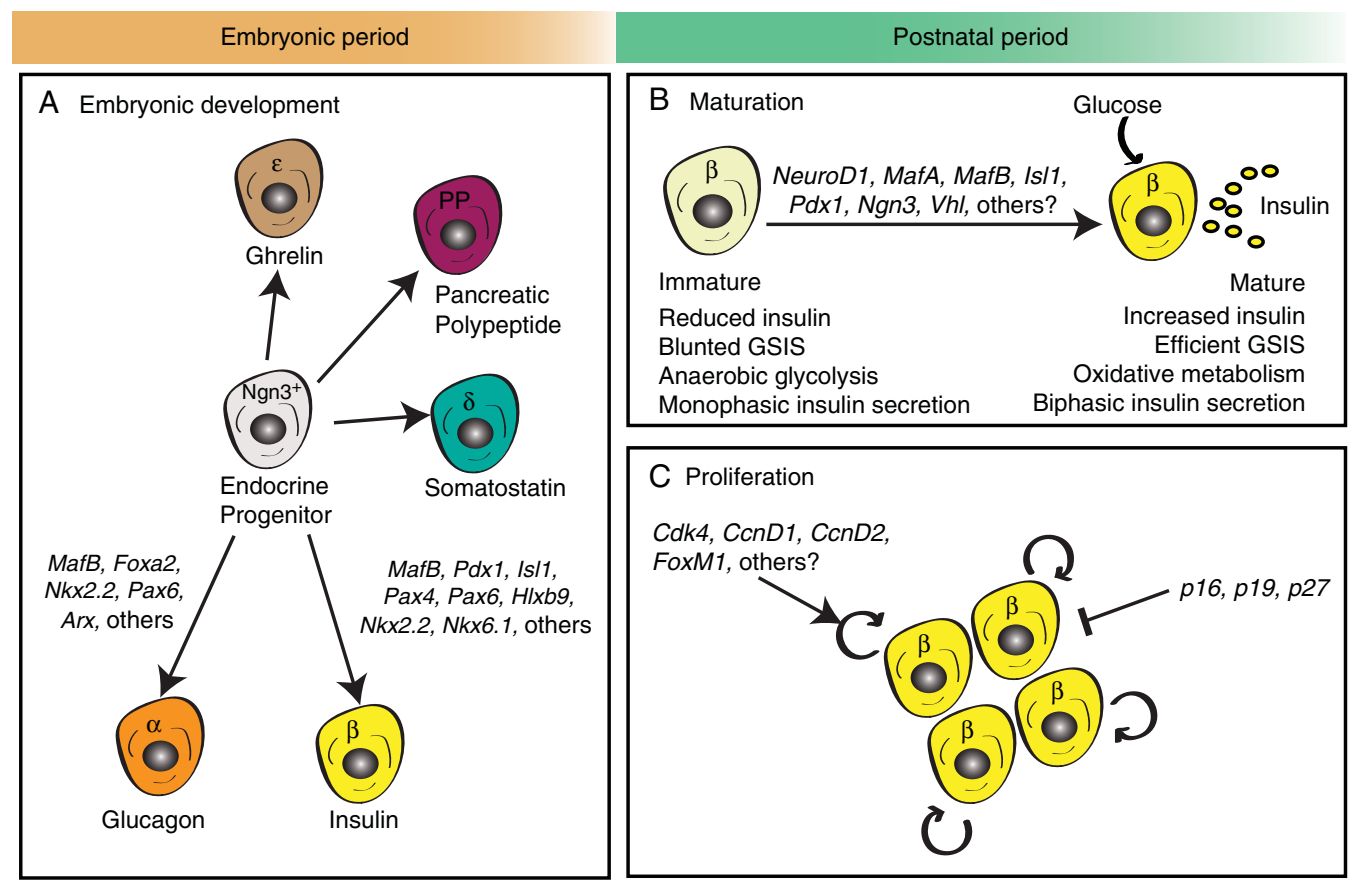

Figure 4. Embryonic and postnatal development of pancreatic endocrine cells. (A) During embryonic development, pancreatic endocrine cells are formed by differentiation from progenitor cells expressing the bHLH transcription factor Neurogenin3 (Ngn3). Differentiation into distinct lineages requires the expression of a cascade of different transcriptional factors (TFs). Key $\alpha$-cell TFs include Forkhead box A2 (Foxa2), NK2 homeobox 2 (Nkx2.2), Paired box 6 (Pax6), and aristaless (Arx), whereas $\beta$-cell differentiation requires expression of musculoaponeurotic fibrosarcoma oncogene homolog B (MafB), Pancreatic and duodenal homeobox 1 (Pdx1), Homeobox protein HB9 (Hlxb9), Pax4, Pax6, Islet1 (Isl1), Nkx2.2, and Nkx6.1 among others $(B, C)$. During the "postnatal period" (loosely defined here as "birth until weaning" in mice and "birth until adolescence" in humans), $\beta$ cells undergo two critical events that enable the establishment of a normal, functional $\beta$-cell mass. (B) First, $\beta$ cells undergo functional maturation by increasing insulin production and enhancing glucose-stimulated insulin secretion (GSIS). Known transcriptional regulators of the maturation process include Neurogenic differentiation 1 (NeuroD1), MafA, MafB, Isl1, Pdx1, Ngn3, and Von Hippel-Lindau (Vhl). (C) Second, $\beta$ cells undergo a transient burst of $\beta$-cell proliferation that coincides with a significant increase in $\beta$-cell mass expansion. Cell-cycle regulators of this process include cyclin-dependent kinases (Cdk4), D-type cyclins (CcnD1 and CcnD2), CDK inhibitors (CKIs-p1 $6^{I N K 4 a}, p 19^{A r f}$, and $p 27^{\text {Kipl }}$ ), and the transcription factor FoxM1. Refer to text, Table 1, and cited references for further information.

aplasia (Hancock et al. 2010). Thus, Arx is required both for $\alpha$-cell fate acquisition and repression of non- $\alpha$-cell fate commitment. In contrast, Pax4 is a homeodomain factor required for $\beta$-cell and $\delta$-cell development. In Pax4 mutant mice $\alpha$-cell hyperplasia develops (Sosa-Pineda et al. 1997). Consistent with these phenotypes, recent studies provide evidence for mutual cross-repression of Arx and Pax4 (Collombat et al. 2003, 2009). In $\beta$ cells, Arx silencing has been found to be reinforced by the Dnmt1 and Dnmt3a DNA methyltransferase. Conditional inactivation of Dnmt1 or Dnmt3a in $\beta$ cells led to derepression of Arx and glucagon, leading to their conversion toward an $\alpha$-cell phenotype (Dhawan et al. 2011; Papizan et al 2011, respectively). It seems self-evident that investigating the transcriptional and epigenetic regulatory mechanisms that establish and stabilize $\alpha$-cell fate will be essential for understanding the development of all pancreatic islet cells.

\subsection{Regulation of Islet $\alpha$-Cell Mass}

Unlike recent growth in our understanding of the mechanisms regulating $\beta$-cell proliferation and growth in embryos and adult mice (Heit et al. 2006b), we know little about regulation of $\alpha$-cell proliferation and expansion. $\alpha$-Cell hyperplasia was observed in mice with targeted loss of glucagon receptor, preproglucagon, or the proglucagon-processing endopeptidase called prohormone convertase 2 (Wang et al. 2001; Gelling et al. 2003; Hayashi et al. 2009); however, it was unclear from these studies if hypoglycemia, hypoglucagonemia, or some other factor served as the stimulus for this $\alpha$-cell hyperplasia, and the molecular basis of $\alpha$-cell expansion in these studies was not detailed. In a model of $\alpha$-cell to $\beta$-cell conversion resulting from Pax4 misexpression, Collombat et al. (2009) suggested that hypoglucagonemia stimulated $\alpha$-cell production, based on 
their finding that glucagon replacement suppressed $\alpha$-cell replenishment in this polygenic model. Systems that permit conditional inactivation of glucagon receptor in adult $\alpha$ cells (Thorel et al. 2010) should prove useful for investigating the role of glucagon deficiency in driving $\alpha$-cell hyperplasia in these distinct models.

Prior studies from Pax4 misexpression in the $\alpha$-cell lineage suggested the possibility that $\alpha$-cell neogenesis could be redirected to produce $\beta$ cells (Collombat et al. 2009). However, this investigation also provided evidence for the possibility that postnatal $\alpha$ cells might be converted into functional $\beta$ cells. To assess this possibility directly, Herrera and colleagues have recently used targeted conditional $\beta$-cell destruction combined with lineage tracing in mice (Thorel et al. 2010). These workers concluded that nearly complete $\beta$-cell destruction stimulated native programs to permit some $\alpha$-cell to $\beta$-cell conversion, although the overall levels of this conversion were low. What are the molecular mechanisms regulating this conversion? If identified and harnessed, such knowledge might prove useful for developing both $\beta$ cell and non- $\beta$-cell sources of replacement islets for diabetes.

It seems likely that silencing of $A r x$ combined with expression of Pax4 will be one observation made in settings of adult $\alpha$-cell to $\beta$-cell conversion. Studies from $\mathrm{Lu}$ et al. (2010) suggest that epigenetic regulation of $\alpha$-cell fate will likely also underlie such conversion. Remarkably, these workers recently showed that conditional $\alpha$-cell inactivation of Men1, which encodes the protein menin, a tumor suppressor and component of histone methyltransferase complexes in multiple endocrine cell types (Hughes et al. 2004; Yokoyama et al. 2004) leads to development of tumors resembling $\beta$-cell insulinomas. These workers concluded from genetic lineage-tracing studies that insulinomas derived directly from glucagon-producing Men1deficient cells. In contrast, similar findings in a separate study by Shen et al. (2010) were interpreted as evidence for cell nonautonomous regulation of $\beta$-cell growth control, not conversion. Collectively, these and other reports (see Dhawan et al. 2011; Yang et al 2011) provide evidence that manipulation of genetic or epigenetic regulators may be used to redirect islet cell fates.

\section{ISLET $\beta$-CELL DEVELOPMENT}

$\beta$ cells differentiate from pancreatic endocrine progenitor cells expressing $\mathrm{Ngn} 3$ (Gu et al. 2002). Formation of functional glucose-sensing, insulin-secreting $\beta$ cells requires the expression of a cascade of additional transcription factors (summarized in Fig. 4A and expertly reviewed by others: Gittes 2009; Puri and Hebrok 2010; Seymour and Sander 2011;). On differentiation, most fetal $\beta$ cells remain postmitotic until late in gestation (Bouwens and Rooman
2005) and are considered to be functionally "immature" (Asplund et al. 1969; Rozzo et al. 2009). Here we focus on the postnatal development of $\beta$ cells that culminates in their functional maturation and proliferation to establish an appropriate functional $\beta$-cell mass.

\section{1 $\beta$-Cell Maturation}

Mature $\beta$ cells are capable of sensing glucose and other secretagogues, and, in turn, secreting appropriate levels of insulin to match these physiological signals. Fetal insulin ${ }^{+} \beta$ cells originating from the wave of $\beta$-cell development in the secondary transition appear on E13.5, but these immature $\beta$ cells have a reduced ability to both synthesize and secrete insulin in response to secretagogues (Asplund et al. 1969; Boschero et al. 1990; Rozzo et al. 2009). From birth, confronted with new host energy sources and requirements, the newborn $\beta$ cell rapidly matures. Although this facultative development has been recognized for $>40$ years, the mechanisms underlying this postnatal "maturation" remain unclear. Immature fetal and neonatal $\beta$ cells are defined by several physiological hallmarks, including decreased low $\mathrm{K}_{\text {ATP }}$ resting conductance and high voltage-gated $\mathrm{Ca}^{2+}$ conductance (summarized in Table 1). Compared to adult $\beta$ cells, these neonatal $\beta$-cell properties manifest as a relatively depolarized resting membrane potential accompanied by increased basal insulin secretion (Rozzo et al. 2009). Lactate dehydrogenase A (LDHA), although normally low in mature $\beta$ cells (Sekine et al. 1994; Schuit et al. 1997), is high in immature $\beta$ cells (Boschero et al. 1990; Gu et al. 2010). Thus, glycolysis, not oxidative metabolism, predominates in neonatal islets, resulting in higher levels of lactate production, reduced relative ATP generation, and blunted glucose-stimulated insulin secretion (GSIS) (Asplund and Hellerström 1972; Ishihara et al. 1999; Rozzo et al. 2009). Finally, although immature $\beta$ cells do show increased basal rates of $\mathrm{O}_{2}$ consumption, they fail to increase their oxidative metabolism in response to high glucose exposure as compared to mature $\beta$ cells, and therefore insulin secretion is lower and monophasic, rather than biphasic as in adult islets (Freinkel et al. 1984; Hole et al. 1988).

\subsection{Physiological and Molecular Markers of $\beta$-Cell Maturity}

Physiological $\beta$-cell maturation is accompanied by changes in expression of several markers. In addition to LDHA, fetal and neonatal $\beta$ cells have increased expression of NPY, an inhibitor of adenylyl cyclase (Motulsky and Michel 1988) that enhances $\beta$-cell GSIS (Imai et al. 2007; Myrsén-Axcrona et al. 1997a,b; Whim 2011). Microarray studies have begun to unveil the gene-expression landscape of maturing islets and revealed altered expression of $\beta$-cell surface 
C.M. Benitez et al.

Table 1. "Immature" $\beta$-cell physiological and molecular characteristics, and known transcriptional regulators of $\beta$-cell maturation

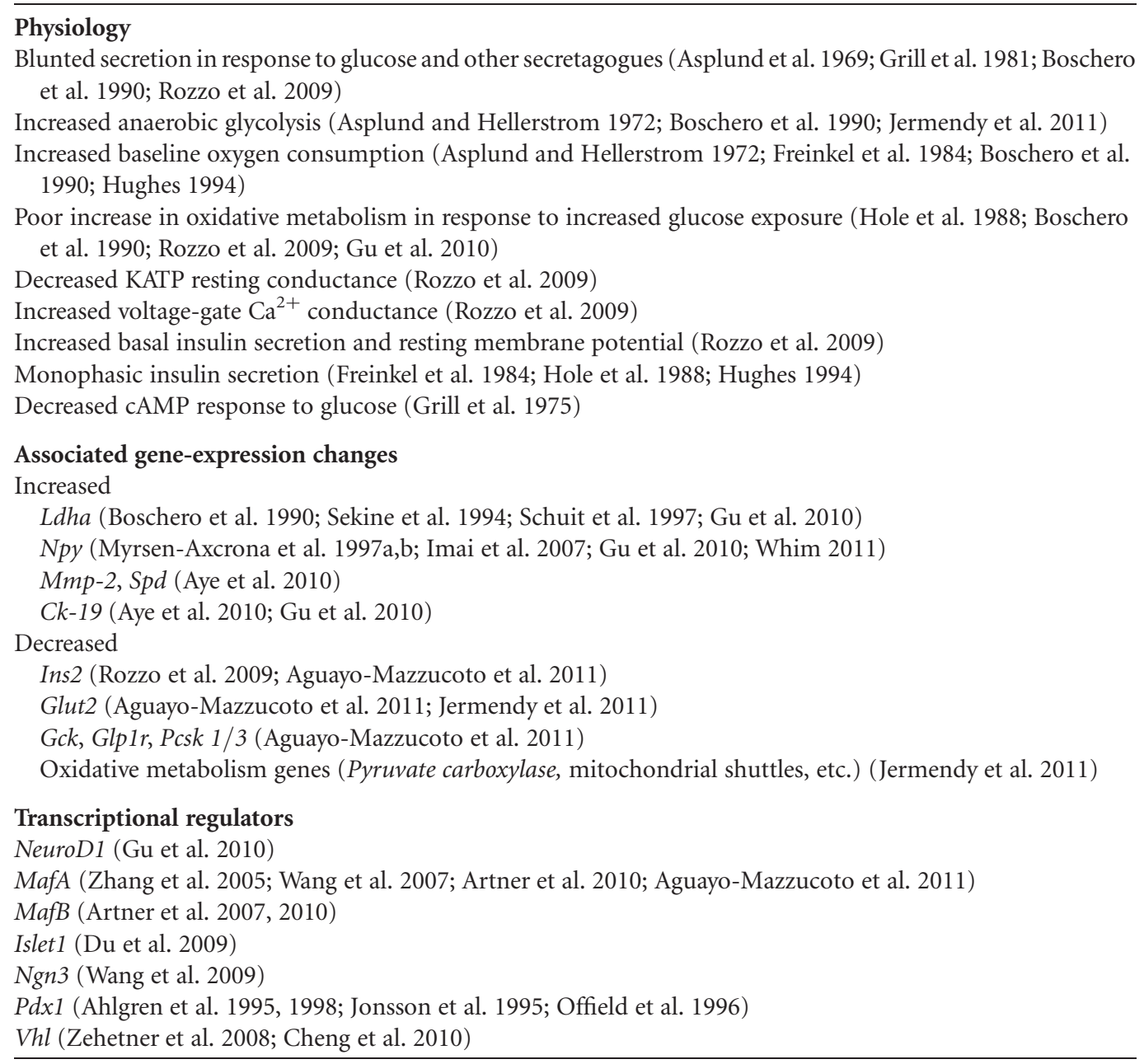

markers and genes encoding regulators of oxidative metabolism (Table 1) (Aye et al. 2010; Gu et al. 2010; Jermendy et al. 2011). Recently, Aguayo-Mazzucato et al. (2011) showed that in newborn rat islets, $\beta$-cell mRNAs encoding Insulin2, Glut2, Glucokinase, and Pcsk1/3, were expressed at roughly $10 \%$ of levels in adult $\beta$ cells. Over the neonatal period, expression levels of these genes increased to adult levels (Aguayo-Mazzucato et al. 2011; C Benitez and SK Kim, unpubl.). It is likely that similar changes accompany maturation of islet $\beta$ cells in mice and humans. If so, flow cytometry-based methods to isolate $\beta$ cells at specific postnatal stages should refine our understanding of $\beta$-cell maturation.

\subsection{Regulators of $\beta$-Cell Maturation}

Transcriptional regulators of $\beta$-cell maturation include $P d x 1$ and NeuroD1 (Fig. 4B), both showing transiently increased expression between birth and weaning (Aguayo-
Mazzucato et al. 2011). Pdx1 is known to regulate the expression of key $\beta$-cell genes including Ins2, Glut2, Gck, and $I A P P$, and $P d x 1$ inactivation in mice resulted in reduced $\beta$ cell function and early-onset diabetes (Ahlgren et al. 1998). Additionally, human PDX1 haploinsufficiency is associated with a rare monogenic form of type 2 diabetes called maturity onset diabetes of the young (MODY4), indicating conservation of Pdx1 activity in $\beta$-cell identity and function (Stoffers et al. 1997; reviewed by Murphy et al. 2008). MafA has also been shown to regulate the expression of genes involved in insulin biosynthesis and secretion (Zhang et al. 2005; Wang et al. 2007) and $\beta$ cells lacking MafA are defective in their ability to secrete insulin in response to glucose or arginine (Zhang et al. 2005; Artner et al. 2010). Conversely, overexpression of MafA in neonatal rat islets was sufficient to increase expression of key $\beta$-cell function genes and up-regulate GSIS to levels approaching those of adult $\beta$ cells (Aguayo-Mazzucato et al. 2011). A recent elegant study by Gu et al. (2010) showed roles for NeuroD1 
in establishing and maintaining $\beta$-cell maturity. $\beta$ cells lacking NeuroD1 had defective insulin secretion and resembled immature $\beta$ cells, with increased glycolysis, basal oxygen consumption, and expression of LDHA and NPY. Recent studies have also implicated other possible regulatory factors including MafB (Artner et al. 2007), Islet1 (Du et al. 2009), Ngn3 (Wang et al. 2009), von Hippel Lindau protein (Zehetner et al. 2008), and calcineurin signaling (Fig. 4B) (WR Goodyer and SK Kim, unpubl.). Future studies of regulators of $\beta$-cell maturation will be facilitated by the use of genetically modified mouse strains that permit conditional gene inactivation or expression specifically in adult $\beta$ cells (Wicksteed et al. 2010).

\subsection{Neonatal $\beta$-Cell Proliferation}

In concert with their maturation, $\beta$ cells replicate with relative vigor in neonatal mice and humans, a stage of significant $\beta$-cell expansion thought to modulate diabetes susceptibility (Butler et al. 2007). Studies in mice have identified regulators required for neonatal $\beta$-cell replication and establishment of $\beta$-cell mass, including cyclindependent kinases, D-type cyclins (Rane et al. 1999; Georgia and Bhushan 2004; Kushner et al. 2005), CDK inhibitors (CKIs) (Uchida et al. 2005; Chen et al. 2009), the transcription factor FoxM1 (Zhang et al. 2006), and other factors (Fig. 4C). Islet CcnD2 and FoxM1 mRNA levels are highest in neonatal mice and decline in adults, whereas the opposite is true for $\mathrm{p} 16^{\mathrm{INK} 4 \mathrm{a}}$ and $\mathrm{p} 19^{\mathrm{Arf}}$ indicating that their transcription may regulate and limit $\beta$-cell proliferation. Moreover, it is unknown if these or other factors regulate neonatal $\beta$-cell expansion in humans (Heit et al. 2006a,b). Recently several factors have emerged as transcriptional regulators of these target genes including Islet1 (Du et al. 2009), Survivin (Wu et al. 2009), and Ezh2 (Chen et al. 2009). Further studies will need to validate these factors within human islet neonatal development, and determine if and how $\beta$-cell maturation and proliferation are coordinated during this crucial developmental window.

\section{$7 \beta$-CELL DENSE CORE GRANULE BIOGENESIS}

Although transcriptional regulation has dominated the landscape of $\beta$-cell developmental biology, other fruitful frameworks for organizing investigation exist, including studies of organelle biology and biogenesis. $\beta$ cells have hallmark organelle features including a rich complement of mitochondria, zinc transport systems, and morphologically distinct secretory vesicles, called dense core granules (DCGs). Prior studies have reviewed mitochondrial biogenesis in $\beta$-cell development (see Maechler et al. 2010, and references therein) and here we focus on developmental regulation of DCGs.

DCGs are complex, membrane-bound organelles that originate from the trans-Golgi network (TGN) and reduced DCG number within $\beta$ cells has been associated with decreased insulin secretion in several mouse models of diabetes (Like and Rossini 1976; Bruin et al. 2008; Pechhold et al. 2009). As an inactive prohormone, proinsulin is initially sorted into immature secretory granules (ISGs) within the TGN. Following budding, ISGs undergo a critical maturation process during which several events occur including (1) acidification of the granule lumen, (2) proteolytic processing of proinsulin by proconvertase $1 / 3$ (Pcsk1/3), Pcsk2, and carboxypeptidase E, (3) budding off of missorted proteins, excess membranes, and clathrin coat in constitutivelike vesicles, and (4) acidification and removal of water resulting in the condensation of the granule (Kim et al. 2006; Hou et al. 2009; Suckale and Solimena 2010). The maturation process allows for the crystallization of insulin into a "dense core" of tightly packed hexamers. For more information on the storage, mobilization, and exocytosis of DCGs, we refer to other recent reviews (Kim et al. 2006; Hou et al. 2009; Suckale and Solimena 2010).

In addition to insulin, DCGs harbor several principal protein components including islet amyloid polypeptide (IAPP), endo- and exopeptidases, SNARE complex components and other exocytosis regulators, granins (including chromogranin A [ChgA] and ChgB), and transmembrane proteins like IA2 (also called ICA152/PTPRN) (Suckale and Solimena 2010). ChgA and ChgB are of particular interest as they have been shown to be both necessary and sufficient for the biogenesis of DCGs by providing a driving force for DCG budding at the TGN (Kim et al. 2001; Day and Gorr 2003; Huh et al. 2003; Mahapatra et al. 2005), although this conclusion has been contested by more recent work (Hendy et al. 2006; Obermüller et al. 2010).

Following $\beta$-cell depolarization, a process mediated by $\mathrm{Ca}^{2+}$ influx and signaling, there is a transient increase in DCG biogenesis to replenish the depleted pools (Kim et al. 2006). Maintenance of DCG stores reflects both transcriptional and posttranscriptional mechanisms. On glucose stimulation, the RNA-binding protein polypyrimidine-tract binding protein 1 (Ptbp1) translocates from the nucleus into the cytoplasm where it binds and stabilizes mRNAs encoding DCG components, thereby promoting biogenesis (Knoch et al. 2004, 2006). The transmembrane protein IA2 has also been implicated as another regulator of DCG formation and insulin secretion, via linked transcriptional and posttranscriptional mechanisms in response to $\beta$-cell depolarization (Saeki et al. 2002; Harashima et al. 2005; 
Kubosaki et al. 2005; Mziaut et al. 2006). These studies, mostly in vitro, suggest how activity-dependent regulation maintains DCGs in adult $\beta$ cells, but it remains unclear how $\mathrm{Ca}^{2+}$-dependent pathways might regulate transcription of hallmark DCG components like insulin, granins, and IAPP in postnatal $\beta$ cells, or how $\beta$-cell DCG formation is regulated in vivo. Diabetes in humans and experimental animals exposed to calcineurin inhibitors like tacrolimus (FK506) and cyclosporin A, and studies of conditional $C n b 1$ inactivation in mice suggest that calcineurin pathways may regulate $\beta$-cell functions (reviewed in Heit $2006 \mathrm{~b}$ ), but it remains unclear if these factors regulate transcription or assembly of $\beta$-cell DCG components. Identification of the mechanisms regulating hallmark features of $\beta$-cell maturation like DCG formation should enhance efforts to create replacement islet cells from multipotent stem cell sources (reviewed by van Hoof et al. 2009; McKnight et al. 2010).

\section{CONCLUDING REMARKS}

Efforts to improve knowledge about mechanisms governing development and growth of the pancreas are rooted in the conviction that such knowledge will prove relevant to diagnosing, prognosing, or treating diverse, common diseases like diabetes mellitus and pancreatic adenocarcinoma. Based on its emergence as a paradigm of solid organ development, these efforts may also help to transform our conception of development and maintenance of cell fate and physiological function in other epithelial organs. To achieve specific goals of regenerative therapy, like $\beta$-cell regeneration in diabetes, a focused effort on deciphering the genetic and epigenetic mechanisms underlying pancreas development is essential. However, aspects of pancreas cell biology and development, including epithelial morphogenesis, organelle biogenesis, and physiological maturation deserve increased attention. A major "roadblock" to progress in these areas will be the accessibility of human tissues and the development of tools and assays to study human pancreas cell biology.

A more integrative approach to pancreas development may prove useful in treating various pancreatic diseases. Pancreas cancers that present at late stages are rapidly fatal; in contrast, discovery and surgical excision of the rarer subset of local tumors is often curative. We foresee that a combinatorial approach to pancreas developmental biology may permit prospective modeling of the first stages of human pancreatic intraepithelial neoplasia (PanIN). Combined with epigenetic and high-throughput sequencing approaches (Ting et al. 2011), these approaches could accelerate development of diagnostic strategies for detecting pancreatic adenocarcinoma at earlier, resectable stages.
Likewise, development of similar approaches may permit detection of $\beta$-cell destruction, presaging type 1 diabetes mellitus, in "preclinical" stages (Akirav et al. 2011). If so, further destruction might be prevented by judicious use of immunosuppression; preservation of $\beta$-cell mass might then expand subsequent regenerative "treatment" options. For type 2 diabetes mellitus, whose origins reflect a multiplicity of pathogenetic mechanisms, induced pluripotent stem cell-based modeling of islet cell growth and adaptation should permit molecular studies to investigate the basis of $\beta$-cell failure risk in this disease, including investigations focused on the multiple candidate loci implicated by GWAS (reviewed by Billings and Florez 2010; Imamura and Maeda 2011). Thus, we envision that developmental and molecular studies of pancreas biology may specifically accelerate early diagnostic regimes that could significantly impact disease progression and outcomes. These studies should also help to frame and define the acceptable "endpoints," including quality and safety benchmarks, for producing surrogate or replacement functional $\beta$ cells from multipotent stem cell sources.

\section{ACKNOWLEDGMENTS}

We thank members of the Kim group for advice and support, and Drs. R.J. MacDonald, R. Stein, P. Herrera, and A. Bhushan for helpful comments on the manuscript and stimulating discussions. C.B. was supported by an NIH Developmental Genetics training grant 5 T32 GM00779029 and a predoctoral fellowship from the National Science Foundation; W.G. was supported by funds from the Medical Scientist Training Program (NIH/NIGMS) and the American Diabetes Association. Work in the Kim group has been supported by the Snyder Foundation, Mead Foundation, Juvenile Diabetes Research Foundation, California Institute of Regenerative Medicine, the Helmsley Charitable Trust, the U.S. NIH, and the Howard Hughes Medical Institute (HHMI). S.K.K. is an Investigator of the HHMI. We apologize to colleagues whose work we could not cite because of space constraints.

\section{REFERENCES}

Aguayo-Mazzucato C, Koh A, El Khattabi I, Li W-C, Toschi E, Jermendy A, Juhl K, Mao K, Weir GC, Sharma A, et al. 2011. Mafa expression enhances glucose-responsive insulin secretion in neonatal rat $\beta$ cells. Diabetologia 54: 583-593.

Ahlgren U, Jonsson J, Edlund H. 1996. The morphogenesis of the pancreatic mesenchyme is uncoupled from that of the pancreatic epithelium in IPF/PDX1-deficient mice. Development 122: 1409-1416.

Ahlgren U, Jonsson J, Jonsson L, Simu K, Edlund H. 1998. $\beta$-cell-specific inactivation of the mouse Ipf1/Pdxl gene results in loss of the $\beta$-cell phenotype and maturity onset diabetes. Genes Dev 12: 1763-1768.

Akirav EM, Lebastchi J, Galvan EM, Henegariu O, Akirav M, Ablamunitis V, Lizardi PM, Herold KC. 2011. Detection of $\beta$ cell death in diabetes 
using differentially methylated circulating DNA. Proc Natl Acad Sci 108: $19018-19023$.

Apelqvist A, Li H, Sommer L, Beatus P, Anderson DJ, Honjo T, Hrabe de Angelis M, Lendahl U, Edlund H. 1999. Notch signalling controls pancreatic cell differentiation. Nature 400: 877-881.

Artner I, Le Lay J, Hang Y, Elghazi L, Schisler JC, Henderson E, SosaPineda B, Stein R. 2006. MafB: An activator of the glucagon gene expressed in developing islet $\alpha$ - and $\beta$-cells. Diabetes 55: 297-304.

Artner I, Blanchi B, Raum JC, Guo M, Kaneko T, Cordes S, Sieweke M, Stein R. 2007. MafB is required for islet $\beta$ cell maturation. Proc Natl Acad Sci 104: 3853-3858.

Artner I, Hang Y, Mazur M, Yamamoto T, Guo M, Linder J, Magnuson MA, Stein R. 2010. MafA and MafB regulate genes critical to $\beta$-cells in a unique temporal manner. Diabetes 59: 2530-2539.

Asplund K, Hellerström C. 1972. Glucose metabolism of pancreatic islets isolated from neonatal rats. Horm Metab Res 4: 159-163.

Asplund K, Westman S, Hellerström C. 1969. Glucose stimulation of insulin secretion from the isolated pancreas of foetal and newborn rats. Diabetologia 5: 260-262.

Aye T, Toschi E, Sharma A, Sgroi D, Bonner-Weir S. 2010. Identification of markers for newly formed $\beta$-cells in the perinatal period: A time of recognized $\beta$-cell immaturity. J Histochem Cytochem 58: 369-376.

Beres TM, Masui T, Swift GH, Shi L, Henke RM, MacDonald RJ. 2006. PTF1 is an organ-specific and Notch-independent basic helix-loophelix complex containing the mammalian Suppressor of Hairless (RBP-J) or its paralogue, RBP-L. Mol Cell Biol 26: 117-130.

Beucher A, Martin M, Spenle C, Poulet M, Collin C, Gradwohl G. 2011. Competence of failed endocrine progenitors to give rise to acinar but not ductal cells is restricted to early pancreas development. Dev Biol 361: $277-285$.

Billings LK, Florez JC. 2010. The genetics of type 2 diabetes: What have we learned from GWAS? Ann NY Acad Sci 1212: 59-77.

Blaine SA, Ray KC, Anunobi R, Gannon MA, Washington MK, Means AL. 2010. Adult pancreatic acinar cells give rise to ducts but not endocrine cells in response to growth factor signaling. Development 137: 2289-2296.

Bonner-Weir S. 2000. Islet growth and development in the adult. J Mol Endocrinol 24: 297-302.

Boschero AC, Bordin S, Sener A, Malaisse WJ. 1990. D-glucose and L-leucine metabolism in neonatal and adult cultured rat pancreatic islets. Mol Cell Endocrinol 73: 63-71.

Bouwens L, Rooman I. 2005. Regulation of pancreatic $\beta$-cell mass. Physiol Rev 85: 1255-1270.

Braganza JM, Lee SH, McCloy RF, McMahon MJ. 2011. Chronic pancreatitis. Lancet 377: 1184-1197.

Bramswig NC, Kaestner KH. 2011. Transcriptional regulation of $\alpha$-cell differentiation. Diabetes Obes Metab 13: 13-20.

Brissova M, Shostak A, Shiota M, Wiebe PO, Poffenberger G, Kantz J, Chen Z, Carr C, Jerome WG, Chen J, et al. 2006. Pancreatic islet production of vascular endothelial growth factor-A is essential for islet vascularization, revascularization, and function. Diabetes 55: 29742985.

Bruin JE, Petre MA, Raha S, Morrison KM, Gerstein HC, Holloway AC. 2008. Fetal and neonatal nicotine exposure in Wistar rats causes progressive pancreatic mitochondrial damage and beta cell dysfunction. PLoS ONE 3: e3371.

Butler PC, Meier JJ, Butler AE, Bhushan Anil. 2007. The replication of $\beta$ cells in normal physiology, in disease and for therapy. Nat Clin Pract Endocrinol Metab 3: 758-768.

Chen H, Gu X, Su I-hsin, Bottino R, Contreras JL, Tarakhovsky A, Kim SK. 2009. Polycomb protein Ezh2 regulates pancreatic $\beta$-cell Ink4a/ Arf expression and regeneration in diabetes mellitus. Genes Dev 23: 975-985.

Cheng K, Ho K, Stokes R, Scott C, Lau SM, Hawthorne WJ, O Connell PJ, Loudovaris T, Kay TW, Kulkami RN, et al. 2010. Hypoxia-inducible factor- $1 \alpha$ regulates $\beta$ cell function in mouse and human islets. J Clin Invest 120: $2171-2183$.
Collombat P, Mansouri A, Hecksher-Sorensen J, Serup P, Krull J, Gradwohl G, Gruss P. 2003. Opposing actions of Arx and Pax4 in endocrine pancreas development. Genes Dev 17: 2591-2603.

Collombat P, Hecksher-Sorensen J, Krull J, Berger J, Riedel D, Herrera PL, Serup P, Mansouri A. 2007. Embryonic endocrine pancreas and mature $\beta$ cells acquire $\alpha$ and PP cell phenotypes upon Arx misexpression. J Clin Invest 117: 961-970.

Collombat P, Xu X, Ravassard P, Sosa-Pineda B, Dussaud S, Billestrup N, Madsen OD, Serup P, Heimberg H, Mansouri A. 2009. The ectopic expression of Pax4 in the mouse pancreas converts progenitor cells into $\alpha$ and subsequently $\beta$ cells. Cell 138: 449-462.

Collombat P, Xu X, Heimberg H, Mansouri A. 2010. Pancreatic $\beta$-cells: From generation to regeneration. Semin Cell Dev Biol 21: 838-844.

Day R, Gorr SU. 2003. Secretory granule biogenesis and chromogranin A: Master gene, on/off switch or assembly factor? Trends Endocrinol Metab 14: 10-13.

Desai BM, Oliver-Krasinski J, De Leon DD, Farzad C, Hong N, Leach SD, Stoffers DA. 2007. Preexisting pancreatic acinar cells contribute to acinar cell, but not islet $\beta$ cell, regeneration. J Clin Invest 117: 971-977.

Desgraz R, Herrera PL. 2009. Pancreatic neurogenin 3-expressing cells are unipotent islet precursors. Development 136: 3567-3574.

Desgraz R, Bonal C, Herrera PL. 2011. $\beta$-cell regeneration: The pancreatic intrinsic faculty. Trends Endocrinol Metab 22: 34-43.

Dhawan S, Georgia S, Tschen SI, Fan G, Bhushan A. 2011. Pancreatic $\beta$ cell identity is maintained by DNA methylation-mediated repression of Arx. Dev Cell 20: 419-429.

Dong PD, Provost E, Leach SD, Stainier DY. 2008. Graded levels of Ptfla differentially regulate endocrine and exocrine fates in the developing pancreas. Genes Dev 22: 1445-1450.

Dorrell C, Grompe MT, Pan FC, Zhong Y, Canaday PS, Shultz LD, Greiner DL, Wright CV, Streeter PR, Grompe M. 2011a. Isolation of mouse pancreatic $\alpha, \beta$, duct, and acinar populations with cell surface markers. Mol Cell Endocrinol 339: 144-150.

Dorrell C, Schu J, Lin CF, Canaday PS, Fox AJ, Smirnova O, Bonnah R, Streeter PR, Stoeckert CJ, Kaestner KH, et al. 2011b. Transcriptomes of major human pancreatic cell types. Diabetologia 54: 2832-2844.

Du A, Hunter CS, Murray J, Noble D, Cai C-L, Evans SM, Stein R, May CL. 2009. Islet-1 is required for the maturation, proliferation, and survival of the endocrine pancreas. Diabetes 58: 2059-2069.

Duvillie B, Attali M, Bounacer A, Ravassard P, Basmaciogullari A, Scharfmann R. 2006. The mesenchyme controls the timing of pancreatic $\beta$ cell differentiation. Diabetes 55: 582-589.

Eberhard D, Lammert E. 2009. The pancreatic $\beta$-cell in the islet and organ community. Curr Opin Genet Dev 19: 469-475.

Edgerton DS, Cherrington AD. 2011. Glucagon as a critical factor in the pathology of diabetes. Diabetes 60: 377-380.

Esni F, Ghosh B, Biankin AV, Lin JW, Albert MA, Yu X, MacDonald RJ, Civin CI, Real FX, Pack MA, et al. 2004. Notch inhibits Ptf1 function and acinar cell differentiation in developing mouse and zebrafish pancreas. Development 131: 4213-4224.

Freinkel N, Lewis NJ, Johnson R, Swenne I, Bone A, Hellerström C. 1984. Differential effects of age versus glycemic stimulation on the maturation of insulin stimulus-secretion coupling during culture of fetal rat islets. Diabetes 33: 1028-1038.

Furuyama K, Kawaguchi Y, Akiyama H, Horiguchi M, Kodama S, Kuhara T, Hosokawa S, Elbahrawy A, Soeda T, Koizumi M, et al. 2011. Continuous cell supply from a Sox9-expressing progenitor zone in adult liver, exocrine pancreas and intestine. Nat Genet 43: 34-41.

Gelling RW, Du XQ, Dichmann DS, Romer J, Huang H, Cui L, Obici S, Tang B, Holst JJ, Fledelius C, et al. 2003. Lower blood glucose, hyperglucagonemia, and pancreatic $\alpha$ cell hyperplasia in glucagon receptor knockout mice. Proc Natl Acad Sci 100: 1438-1443.

Georgia S, Bhushan A. 2004. $\beta$ cell replication is the primary mechanism for maintaining postnatal $\beta$ cell mass. J Clin Invest 114: 963-968.

Githens S. 1988. The pancreatic duct cell: Proliferative capabilities, specific characteristics, metaplasia, isolation, and culture. J Pediatr Gastroenterol Nutr 7: 486-506. 
Gittes GK. 2009. Developmental biology of the pancreas: A comprehensive review. Dev Biol 326: 4-35.

Gosmain Y, Marthinet E, Cheyssac C, Guérardel A, Mamin A, Katz LS, Bouzakri K, Philippe J. 2010. Pax6 controls the expression of critical genes involved in pancreatic $\alpha$ cell differentiation and function. J Biol Chem 285: 33381-33393.

Gosmain Y, Cheyssac C, Heddad Masson M, Dibner C, Philippe J. 2011. Glucagon gene expression in the endocrine pancreas: The role of the transcription factor Pax6 in $\alpha$-cell differentiation, glucagon biosynthesis and secretion. Diabetes Obes Metab 13: 31-38.

Grill V. 1981. Time and dose dependencies for priming effect of glucose on insulin secretion. Am J Physiol 240: E24-E31.

Grill V, Asplund K, Hellerström C, Cerasi E. 1975. Decreased cyclic AMP and insulin response to glucose in isolated islets of neonatal rats. Diabetes 24: 746-752.

Gromada J, Franklin I, Wollheim CB. 2007. $\alpha$-cells of the endocrine pancreas: 35 years of research but the enigma remains. Endocr Rev 28: 84-116.

Gu G, Dubauskaite J, Melton DA. 2002. Direct evidence for the pancreatic lineage: $\mathrm{NGN}^{+}$cells are islet progenitors and are distinct from duct progenitors. Development 129: 2447-2457.

Gu C, Stein GH, Pan N, Goebbels S, Hörnberg H, Nave K-A, Herrera P, White P, Kaestner KH, Sussel L, et al. 2010. Pancreatic $\beta$ cells require NeuroD to achieve and maintain functional maturity. Cell Metab 11: $298-310$.

Gurda GT, Guo L, Lee SH, Molkentin JD, Williams JA. 2008. Cholecystokinin activates pancreatic calcineurin-NFAT signaling in vitro and in vivo. Mol Biol Cell 19: 198-206.

Gurda GT, Crozier SJ, Ji B, Ernst SA, Logsdon CD, Rothermel BA, Williams JA. 2010. Regulator of calcineurin 1 controls growth plasticity of adult pancreas. Gastroenterology 139: 609-619.

Hald J, Sprinkel AE, Ray M, Serup P, Wright C, Madsen OD. 2008. Generation and characterization of Ptfla antiserum and localization of Ptfla in relation to Nkx6.1 and Pdx1 during the earliest stages of mouse pancreas development. J Histochem Cytochem 56: 587-595.

Hancock AS, Du A, Liu J, Miller M, May CL. 2010. Glucagon deficiency reduces hepatic glucose production and improves glucose tolerance in adult mice. Mol Endocrinol 24: 1605-1614.

Harashima S-ichi, Clark A, Christie MR, Notkins AL. 2005. The dense core transmembrane vesicle protein IA-2 is a regulator of vesicle number and insulin secretion. Proc Natl Acad Sci 102: 8704-8709.

Haumaitre C, Barbacci E, Jenny M, Ott MO, Gradwohl G, Cereghini S. 2005. Lack of TCF2/vHNF1 in mice leads to pancreas agenesis. Proc Natl Acad Sci 102: 1490-1495.

Haumaitre C, Lenoir O, Scharfmann R. 2008. Histone deacetylase inhibitors modify pancreatic cell fate determination and amplify endocrine progenitors. Mol Cell Biol 28: 6373-6383.

Hayashi Y, Yamamoto M, Mizoguchi H, Watanabe C, Ito R, Yamamoto S, Sun XY, Murata Y. 2009. Mice deficient for glucagon gene-derived peptides display normoglycemia and hyperplasia of islet $\alpha$-cells but not of intestinal L-cells. Mol Endocrinol 23: 1990-1999.

Heit JJ, Apelqvist AA, Gu X, Winslow MM, Neilson JR, Crabtree GR, Kim SK. 2006a. Calcineurin/NFAT signalling regulates pancreatic $\beta$-cell growth and function. Nature 443: 345-349.

Heit JJ, Karnik SK, Kim SK. 2006b. Intrinsic regulators of pancreatic $\beta$ cell proliferation. Annu Rev Cell Dev Biol 22: 311-338.

Hendy GN, Li T, Girard M, Feldstein RC, Mulay S, Desjardins R, Day R, Karaplis AC, Tremblay ML, Canaff L. 2006. Targeted ablation of the chromogranin a (Chga) gene: Normal neuroendocrine dense-core secretory granules and increased expression of other granins. Mol Endocrinol 20: 1935-1947.

Henseleit KD, Nelson SB, Kuhlbrodt K, Hennings JC, Ericson J, Sander M. 2005. NKX6 transcription factor activity is required for $\alpha$ - and $\beta$ cell development in the pancreas. Development 132: 3139-3149.

Herrera PL, Huarte J, Sanvito F, Meda P, Orci L, Vassalli JD. 1991. Embryogenesis of the murine endocrine pancreas; early expression of pancreatic polypeptide gene. Development 113: 1257-1265.
Hesselson D, Anderson RM, Stainier DY. 2011. Suppression of Ptfla activity induces acinar-to-endocrine conversion. Curr Biol 21: 712 717.

Hick AC, Pierreux CE, van Eyll JM, Cordi S, Forez C, Passante L, Kohara H, Nagasawa T, Vanderhaeghen P, Courtoy PJ, et al. 2009. Mechanism of primitive duct formation in the pancreas and submandibular glands: A role for SDF-1. BMC Dev Biol 9: 66.

Hole RL, Pian-Smith MC, Sharp GW. 1988. Development of the biphasic response to glucose in fetal and neonatal rat pancreas. Am J Physiol 254: E167-E174.

Hou JC, Min L, Pessin JE. 2009. Insulin granule biogenesis, trafficking and exocytosis. Vitam Horm 80: 473-506.

Hughes SJ. 1994. The role of reduced glucose transporter content and glucose metabolism in the immature secretory responses of fetal rat pancreatic islets. Diabetologia 37: 134-140.

Hughes CM, Rozenblatt-Rosen O, Milne TA, Copeland TD, Levine SS, Lee JC, Hayes DN, Shanmugam KS, Bhattacharjee A, Biondi CA, et al. 2004. Menin associates with a trithorax family histone methyltransferase complex and with the hoxc8 locus. Mol Cell 13: 587-597.

Huh YH, Jeon SH, Yoo SH. 2003. Chromogranin B-induced secretory granule biogenesis: Comparison with the similar role of chromogranin A. J Biol Chem 278: 40581-40589.

Imai Y, Patel HR, Hawkins EJ, Doliba NM, Matschinsky FM, Ahima RS. 2007. Insulin secretion is increased in pancreatic islets of neuropeptide Y-deficient mice. Endocrinology 148: 5716-5723.

Imamura M, Maeda S. 2011. Genetics of type 2 diabetes: The GWAS era and future perspectives. Endocr J 58: 723-739.

Inada A, Nienaber C, Katsuta H, Fujitani Y, Levine J, Morita R, Sharma A, Bonner-Weir S. 2008. Carbonic anhydrase II-positive pancreatic cells are progenitors for both endocrine and exocrine pancreas after birth. Proc Natl Acad Sci 105: 19915-19919.

Ishihara H, Wang H, Drewes LR, Wollheim CB. 1999. Overexpression of monocarboxylate transporter and lactate dehydrogenase alters insulin secretory responses to pyruvate and lactate in $\beta$ cells. J Clin Invest 104: $1621-1629$.

Jermendy A, Toschi E, Aye T, Koh A, Aguayo-Mazzucato C, Sharma A, Weir GC, Sgroi D, Bonner-Weir S. 2011. Rat neonatal $\beta$ cells lack the specialised metabolic phenotype of mature $\beta$ cells. Diabetologia 54: 594-604.

Jia D, Sun Y, Konieczny SF. 2008. Mist1 regulates pancreatic acinar cell proliferation through p21 CIP1/WAF1. Gastroenterology 135: 1687-1697.

Johansson KA, Dursun U, Jordan N, Gu G, Beermann F, Gradwohl G, Grapin-Botton A. 2007. Temporal control of neurogenin3 activity in pancreas progenitors reveals competence windows for the generation of different endocrine cell types. Dev Cell 12: 457-465.

Jonsson J, Ahlgren U, Edlund T, Edlund H. 1995. IPF1, a homeodomain protein with dual function in pancreas development. Int J Dev Biol 39: 789-798.

Jorgensen MC, Ahnfelt-Ronne J, Hald J, Madsen OD, Serup P, HecksherSorensen J. 2007. An illustrated review of early pancreas development in the mouse. Endocr Rev 28: 685-705.

Kawaguchi Y, Cooper B, Gannon M, Ray M, MacDonald RJ, Wright CV. 2002. The role of the transcriptional regulator Ptfla in converting intestinal to pancreatic progenitors. Nat Genet 32: 128-134.

Kawaguchi Y, Takaori K, Uemoto S. 2011. Genetic lineage tracing, a powerful tool to investigate the embryonic organogenesis and adult organ maintenance of the pancreas. J Hepatobiliary Pancreat Sci 18: $1-5$.

Kesavan G, Sand FW, Greiner TU, Johansson JK, Kobberup S, Wu X, Brakebusch C, Semb H. 2009. Cdc42-mediated tubulogenesis controls cell specification. Cell 139: 791-801.

Kim T, Tao-Cheng JH, Eiden LE, Loh Y P. 2001. Chromogranin A, an "on/off" switch controlling dense-core secretory granule biogenesis. Cell 106: 499-509.

Kim T, Gondré-Lewis MC, Arnaoutova I, Loh YP. 2006. Dense-core secretory granule biogenesis. Physiology 21: 124-133. 
Kinkel MD, Prince VE. 2009. On the diabetic menu: Zebrafish as a model for pancreas development and function. Bioessays 31: 139-152.

Knoch K-P, Bergert H, Borgonovo B, Saeger H-D, Altkrüger A, Verkade P, Solimena M. 2004. Polypyrimidine tract-binding protein promotes insulin secretory granule biogenesis. Nat Cell Biol 6: 207-214.

Knoch K-P, Meisterfeld R, Kersting S, Bergert H, Altkrüger A, Wegbrod C, Jäger M, Saeger H-D, Solimena M. 2006. cAMP-dependent phosphorylation of PTB1 promotes the expression of insulin secretory granule proteins in $\beta$ cells. Cell Metab 3: 123-134.

Kopp JL, Dubois CL, Schaffer AE, Hao E, Shih HP, Seymour PA, Ma J, Sander M. 2011. Sox $9^{+}$ductal cells are multipotent progenitors throughout development but do not produce new endocrine cells in the normal or injured adult pancreas. Development 138: 653-665.

Krapp A, Knofler M, Ledermann B, Burki K, Berney C, Zoerkler N, Hagenbuchle O, Wellauer PK. 1998. The bHLH protein PTF1-p48 is essential for the formation of the exocrine and the correct spatial organization of the endocrine pancreas. Genes Dev 12: 3752-3763.

Kubosaki A, Nakamura S, Notkins AL. 2005. Dense core vesicle proteins IA-2 and IA-2 $\beta$ : Metabolic alterations in double knockout mice. Diabetes 54: S46-S51.

Kushner JA, Ciemerych MA, Sicinska E, Wartschow LM, Teta M, Long SY, Sicinski P, White MF. 2005. Cyclins D2 and D1 are essential for postnatal pancreatic $\beta$-cell growth. Mol Cell Biol 25: 3752-3762.

Lee CS, Sund NJ, Behr R, Herrera PL, Kaestner KH. 2005. Foxa2 is required for the differentiation of pancreatic $\alpha$-cells. Dev Biol 278: $484-495$.

Like AA, Rossini AA. 1976. Streptozotocin-induced pancreatic insulitis: New model of diabetes mellitus. Science 193: 415-417.

Lu J, Herrera PL, Carreira C, Bonnavion R, Seigne C, Calender A, Bertolino P, Zhang CX. 2010. $\alpha$ cell-specific Men1 ablation triggers the transdifferentiation of glucagon-expressing cells and insulinoma development. Gastroenterology 138: 1954-1965.

MacDonald RJ, Swift GH, Real FX. 2010. Transcriptional control of acinar development and homeostasis. Prog Mol Biol Transl Sci 97: 1-40.

Maechler P, Li N, Casimir M, Vetterli L, Frigerio F, Brun T. 2010. Role of mitochondria in $\beta$-cell function and dysfunction. Adv Exp Med Biol 654: $193-216$

Magenheim J, Ilovich O, Lazarus A, Klochendler A, Ziv O, Werman R, Hija A, Cleaver O, Mishani E, Keshet E, et al. 2011. Blood vessels restrain pancreas branching, differentiation and growth. Development 138: $4743-4752$.

Mahapatra NR, O'Connor DT, Vaingankar SM, Hikim APS, Mahata M, Ray S, Staite E, Wu H, Gu Y, Dalton N, et al. 2005. Hypertension from targeted ablation of chromogranin A can be rescued by the human ortholog. J Clin Invest 115: 1942-1952.

Masui T, Long Q, Beres TM, Magnuson MA, MacDonald RJ. 2007. Early pancreatic development requires the vertebrate Suppressor of Hairless (RBPJ) in the PTF1 bHLH complex. Genes Dev 21: 2629-2643.

Masui T, Swift GH, Hale MA, Meredith DM, Johnson JE, Macdonald RJ. 2008. Transcriptional autoregulation controls pancreatic Ptfla expression during development and adulthood. Mol Cell Biol 28: 54585468.

Masui T, Swift GH, Deering T, Shen C, Coats WS, Long Q, Elsasser HP, Magnuson MA, MacDonald RJ. 2010. Replacement of Rbpj with Rbpjl in the PTF1 complex controls the final maturation of pancreatic acinar cells. Gastroenterology 139: 270-280.

McKnight KD, Wang P, Kim SK. 2010. Deconstructing pancreas development to reconstruct human islets from pluripotent stem cells. Cell Stem Cell 6: 300-308.

Miralles F, Philippe P, Czernichow P, Scharfmann R. 1998. Expression of nerve growth factor and its high-affinity receptor Trk-A in the rat pancreas during embryonic and fetal life. J Endocrinol 156: 431-439.

Miyamoto Y, Maitra A, Ghosh B, Zechner U, Argani P, Iacobuzio-Donahue CA, Sriuranpong V, Iso T, Meszoely IM, Wolfe MS, et al. 2003. Notch mediates TGF $\alpha$-induced changes in epithelial differentiation during pancreatic tumorigenesis. Cancer Cell 3: 565-576.
Miyatsuka T, Kosaka Y, Kim H, German MS. 2011. Neurogenin3 inhibits proliferation in endocrine progenitors by inducing Cdknla. Proc Natl Acad Sci 108: 185-190.

Morris JPt, Wang SC, Hebrok M. 2010. KRAS, Hedgehog, Wnt and the twisted developmental biology of pancreatic ductal adenocarcinoma. Nat Rev Cancer 10: 683-695.

Motulsky HJ, Michel MC. 1988. Neuropeptide Y mobilizes $\mathrm{Ca}^{2+}$ and inhibits adenylate cyclase in human erythroleukemia cells. Am J Physiol 255: E880-E885.

Murphy R, Ellard S, Hattersley AT. 2008. Clinical implications of a molecular genetic classification of monogenic $\beta$-cell diabetes. Nat Clin Pract Endocrinol Metab 4: 200-213.

Murtaugh LC. 2008. The what, where, when and how of Wnt $/ \beta$-catenin signaling in pancreas development. Organogenesis 4: 81-86.

Murtaugh LC, Law AC, Dor Y, Melton DA. 2005. $\beta$-catenin is essential for pancreatic acinar but not islet development. Development 132: $4663-$ 4674.

Myrsén-Axcrona U, Ekblad E, Sundler F. 1997a. Developmental expression of NPY, PYY and PP in the rat pancreas and their coexistence with islet hormones. Regul Pept 68: 165-175.

Myrsén-Axcrona U, Karlsson S, Sundler F, Ahrén B. 1997b. Dexamethasone induces neuropeptide Y (NPY) expression and impairs insulin release in the insulin-producing cell line RINm5F. Release of NPY and insulin through different pathways. J Biol Chem 272: 10790-10796.

Mziaut H, Trajkovski M, Kersting S, Ehninger A, Altkrüger A, Lemaitre RP, Schmidt D, Saeger H-D, Lee M-S, Drechsel DN, et al. 2006. Synergy of glucose and growth hormone signalling in islet cells through ICA512 and STAT5. Nat Cell Biol 8: 435-445.

Nakhai H, Siveke JT, Klein B, Mendoza-Torres L, Mazur PK, Algul H, Radtke F, Strobl L, Zimber-Strobl U, Schmid RM. 2008a. Conditional ablation of Notch signaling in pancreatic development. Development 135: $2757-2765$.

Nakhai H, Siveke JT, Mendoza-Torres L, Schmid RM. 2008b. Conditional inactivation of Myc impairs development of the exocrine pancreas. Development 135: 3191-3196.

Nishimura W, Kondo T, El Khattabi I, Dodge R, Ho IC, Weir SB, Sharma AJ. 2006. Maf factors are important for the differentiation of pancreatic endocrine cells. Diabetes 55: A362.

Nishimura W, Rowan S, Salameh T, Maas RL, Bonner-Weir S, Sell SM, Sharma A. 2008. Preferential reduction of $\beta$ cells derived from Pax6MafB pathway in MafB deficient mice. Dev Biol 314: 443-456.

Obermüller S, Calegari F, King A, Lindqvist A, Lundquist I, Salehi A, Francolini M, Rosa P, Rorsman P, Huttner WB, et al. 2010. Defective secretion of islet hormones in chromogranin-B deficient mice. PLoS ONE 5: e8936.

Offield MF, Jetton TL, Labosky PA, Ray M, Stein RW, Magnuson M A, Hogan BL, Wright CV. 1996. PDX-1 is required for pancreatic outgrowth and differentiation of the rostral duodenum. Development 122: 983-995.

Oliver-Krasinski JM, Stoffers DA. 2008. On the origin of the $\beta$ cell. Genes Dev 22: 1998-2021.

Pan FC, Wright C. 2011. Pancreas organogenesis: From bud to plexus to gland. Dev Dynam 240: 530-565.

Papizan JB, Singer RA, Tschen SI, Dhawan S, Friel JM, Hipkens SB, Magnuson MA, Bhushan A, Sussel L. 2011. Nkx2.2 repressor complex regulates islet $\beta$-cell specification and prevents $\beta$-to- $\alpha$-cell reprogramming. Genes Dev 25: 2291-2305.

Pechhold K, Koczwara K, Zhu X, Harrison VS, Walker G, Lee J, Harlan DM. 2009. Blood glucose levels regulate pancreatic $\beta$-cell proliferation during experimentally-induced and spontaneous autoimmune diabetes in mice. PLoS ONE 4: e4827.

Pictet RL, Clark WR, Williams RH, Rutter WJ. 1972. An ultrastructural analysis of the developing embryonic pancreas. Dev Biol 29: 436-467.

Pierreux CE, Poll AV, Kemp CR, Clotman F, Maestro MA, Cordi S, Ferrer J, Leyns L, Rousseau GG, Lemaigre FP. 2006. The transcription factor hepatocyte nuclear factor- 6 controls the development of pancreatic ducts in the mouse. Gastroenterology 130: 532-541. 
Pin CL, Rukstalis JM, Johnson C, Konieczny SF. 2001. The bHLH transcription factor Mist1 is required to maintain exocrine pancreas cell organization and acinar cell identity. J Cell Biol 155: 519-530.

Puri S, Hebrok M. 2010. Cellular plasticity within the pancreas-Lessons learned from development. Dev Cell 18: 342-356.

Rane SG, Dubus P, Mettus RV, Galbreath EJ, Boden G, Reddy EP, Barbacid M. 1999. Loss of Cdk4 expression causes insulin-deficient diabetes and Cdk4 activation results in $\beta$-islet cell hyperplasia. Nat Genet 22: $44-52$.

Rozzo A, Meneghel-Rozzo T, Delakorda SL, Yang S-B, Rupnik M. 2009. Exocytosis of insulin: In vivo maturation of mouse endocrine pancreas. Ann NY Acad Sci 1152: 53-62.

Rukstalis JM, Habener JF. 2007. Snail2, a mediator of epithelial-mesenchymal transitions, expressed in progenitor cells of the developing endocrine pancreas. Gene Expr Patterns 7: 471-479.

Rukstalis JM, Habener JF. 2009. Neurogenin3: A master regulator of pancreatic islet differentiation and regeneration. Islets 1: $177-184$.

Saeki K, Zhu M, Kubosaki A, Xie J, Lan MS, Notkins AL. 2002. Targeted disruption of the protein tyrosine phosphatase-like molecule IA-2 results in alterations in glucose tolerance tests and insulin secretion. Diabetes 51: 1842-1850.

Schaffer AE, Freude KK, Nelson SB, Sander M. 2010. Nkx6 transcription factors and Ptfla function as antagonistic lineage determinants in multipotent pancreatic progenitors. Dev Cell 18: 1022-1029.

Schuit F, De Vos A, Farfari S, Moens K, Pipeleers D, Brun T, Prentki M. 1997. Metabolic fate of glucose in purified islet cells. Glucose-regulated anaplerosis in $\beta$ cells. J Biol Chem 272: 18572-18579.

Scott Swenson E, Xanthopoulos J, Nottoli T, McGrath J, Theise ND, Krause DS. 2009. Chimeric mice reveal clonal development of pancreatic acini, but not islets. Biochem Biophys Res Commun 379: $526-531$.

Sekine N, Cirulli V, Regazzi R, Brown LJ, Gine E, Tamarit-Rodriguez J, Girotti M, Marie S, MacDonald MJ, Wollheim CB. 1994. Low lactate dehydrogenase and high mitochondrial glycerol phosphate dehydrogenase in pancreatic $\beta$-cells. Potential role in nutrient sensing. J Biol Chem 269: 4895-4902.

Seymour PA, Sander M. 2011. Historical perspective: Beginnings of the $\beta$-cell: Current perspectives in $\beta$-cell development. Diabetes 60: 364-376.

Sharer N, Schwarz M, Malone G, Howarth A, Painter J, Super M, Braganza J. 1998. Mutations of the cystic fibrosis gene in patients with chronic pancreatitis. N Engl J Med 339: 645-652.

Shen HC, Ylaya K, Pechhold K, Wilson A, Adem A, Hewitt SM, Libutti SK. 2010. Multiple endocrine neoplasia type 1 deletion in pancreatic $\alpha$-cells leads to development of insulinomas in mice. Endocrinology 151: 4024-4030.

Slack JM. 1995. Developmental biology of the pancreas. Development 121: $1569-1580$.

Smith SB, Qu HQ, Taleb N, Kishimoto NY, Scheel DW, Lu Y, Patch AM, Grabs R, Wang J, Lynn FC, et al. 2010. Rfx6 directs islet formation and insulin production in mice and humans. Nature 463: $775-780$.

Solar M, Cardalda C, Houbracken I, Martín M, Maestro MA, De Medts N, Xu X, Grau V, Heimberg H, Bouwens L, et al. 2009. Pancreatic exocrine duct cells give rise to insulin-producing $\beta$ cells during embryogenesis but not after birth. Dev Cell 17: 849-860.

Sosa-Pineda B, Chowdhury K, Torres M, Oliver G, Gruss P. 1997. The Pax4 gene is essential for differentiation of insulin-producing $\beta$ cells in the mammalian pancreas. Nature 386: 399-402.

Soyer J, Flasse L, Raffelsberger W, Beucher A, Orvain C, Peers B, Ravassard P, Vermot J, Voz ML, Mellitzer G, et al. 2010. Rfx6 is an Ngn3dependent winged helix transcription factor required for pancreatic islet cell development. Development 137: 203-212.

Stoffers DA, Zinkin NT, Stanojevic V, Clarke WL, Habener JF. 1997. Pancreatic agenesis attributable to a single nucleotide deletion in the human IPF1 gene coding sequence. Nat Genet 15: 106-110.
Suckale J, Solimena M. 2010. The insulin secretory granule as a signaling hub. Trends Endocrinol Metab 21: 599-609.

Thorel F, Népote V, Avril I, Kohno K, Desgraz R, Chera S, Herrera PL. 2010 . Conversion of adult pancreatic $\alpha$-cells to $\beta$-cells after extreme $\beta$ cell loss. Nature 464: 1149-1154.

Tian X, Jin RU, Bredemeyer AJ, Oates EJ, Blazewska KM, McKenna CE, Mills JC. 2010. RAB26 and RAB3D are direct transcriptional targets of MIST1 that regulate exocrine granule maturation. Mol Cell Biol 30: $1269-1284$.

Ting DT, Lipson D, Paul S, Brannigan BW, Akhavandard S, Coffman EJ, Contino G, Deshpande V, Lafrate AJ, Letovsky S, et al. 2011. Aberrant overexpression of satellite repeats in pancreatic and other epithelial cancers. Science 331: 593-596.

Tremblay KD. 2010. Formation of the murine endoderm: Lessons from the mouse, frog, fish, and chick. Prog Mol Biol Transl Sci 96: p1-p34.

Uchida T, Nakamura T, Hashimoto N, Matsuda T, Kotani K, Sakaue H, Kido Y, Hayashi Y, Nakayama KI, White MF, et al. 2005. Deletion of Cdkn $1 \mathrm{~b}$ ameliorates hyperglycemia by maintaining compensatory hyperinsulinemia in diabetic mice. Nat Med 11: 175-182.

van Hoof D, D'Amour KA, German MS. 2009. Derivation of insulinproducing cells from human embryonic stem cells. Stem Cell Res 3: $73-87$.

Villasenor A, Chong DC, Henkemeyer M, Cleaver O. 2010. Epithelial dynamics of pancreatic branching morphogenesis. Development 137: 4295-4305.

von Burstin J, Reichert M, Wescott MP, Rustgi AK. 2010. The pancreatic and duodenal homeobox protein PDX-1 regulates the ductal specific keratin 19 through the degradation of MEIS1 and DNA binding. PLoS ONE 5: e12311.

Wang X, Zhou J, Doyle ME, Egan JM. 2001. Glucagon-like peptide-1 causes pancreatic duodenal homeobox-1 protein translocation from the cytoplasm to the nucleus of pancreatic $\beta$-cells by a cyclic adenosine monophosphate/protein kinase A-dependent mechanism. Endocrinology 142: 1820-1827.

Wang H, Brun T, Kataoka K, Sharma AJ, Wollheim CB. 2007. MAFA controls genes implicated in insulin biosynthesis and secretion. Diabetologia 50: 348-358.

Wang S, Jensen JN, Seymour PA, Hsu W, Dor Y, Sander M, Magnuson Mark A, Serup P, Gu G. 2009. Sustained Neurog3 expression in hormone-expressing islet cells is required for endocrine maturation and function. Proc Natl Acad Sci 106: 9715-9720.

Wang S, Yan J, Anderson DA, Xu Y, Kanal MC, Cao Z, Wright CV, Gu G. 2010. Neurog3 gene dosage regulates allocation of endocrine and exocrine cell fates in the developing mouse pancreas. Dev Biol 339: 26-37.

Whim MD. 2011. Pancreatic $\beta$ cells synthesize neuropeptide Y and can rapidly release peptide co-transmitters. PLoS ONE 6: e19478.

Wicksteed B, Brissova M, Yan W, Opland DM, Plank JL, Reinert RB, Dickson LM, Tamarina NA, Philipson LH, Shostak A, et al. 2010. Conditional gene targeting in mouse pancreatic $\beta$-cells: Analysis of ectopic Cre transgene expression in the brain. Diabetes 59: 3090-3098.

Wu X, Wang L, Schroer S, Choi D, Chen P, Okada H, Woo M. 2009. Perinatal survivin is essential for the establishment of pancreatic $\beta$ cell mass in mice. Diabetologia 52: 2130-2141.

Xia B, Zhan XR, Yi R, Yang B. 2009. Can pancreatic duct-derived progenitors be a source of islet regeneration? Biochem Biophys Res Commun 383: 383-385.

Xu X, D’Hoker J, Stangé G, Bonné S, De Leu N, Xiao X, Van De Casteele M, Mellitzer G, Ling Z, Pipeleers D, et al. 2008. $\beta$ cells can be generated from endogenous progenitors in injured adult mouse pancreas. Cell 132: 197-207.

Xu CR, Cole PA, Meyers DJ, Kormish J, Dent S, Zaret KS. 2011. Chromatin "prepattern" and histone modifiers in a fate choice for liver and pancreas. Science 332: 963-966.

Yang YP, Thorel F, Boyer DF, Herrera PL, Wright CV. 2011. Contextspecific $\alpha$-to- $\beta$-cell reprogramming by forced Pdx1 expression. Genes Dev 25: $1680-1685$. 
Yokoyama A, Wang Z, Wysocka J, Sanyal M, Aufiero DJ, Kitabayashi I, Herr W, Cleary ML. 2004. Leukemia proto-oncoprotein MLL forms a SET1-like histone methyltransferase complex with menin to regulate Hox gene expression. Mol Cell Biol 24: 5639-5649.

Zaret KS, Grompe M. 2008. Generation and regeneration of cells of the liver and pancreas. Science 322: 1490-1494.

Zehetner J, Danzer C, Collins S, Eckhardt K, Gerber PA, Ballschmieter P, Galvanovskis J, Shimomura K, Ashcroft FM, Thorens B, et al. 2008. PVHL is a regulator of glucose metabolism and insulin secretion in pancreatic $\beta$ cells. Genes Dev 22: 3135-3146.

Zhang C, Moriguchi T, Kajihara M, Esaki R, Harada A, Shimohata H, Oishi H, Hamada M, Morito N, Hasegawa K, et al. 2005. MafA is a key regulator of glucose-stimulated insulin secretion. Mol Cell Biol 25: 4969-4976.
Zhang H, Ackermann AM, Gusarova GA, Lowe D, Feng X, Kopsombut UG, Costa RH, Gannon M. 2006. The FoxM1 transcription factor is required to maintain pancreatic $\beta$-cell mass. Mol Endocrinol 20: $1853-1866$.

Zhang H, Ables ET, Pope CF, Washington MK, Hipkens S, Means AL, Path G, Seufert J, Costa RH, Leiter AB, et al. 2009. Multiple, temporalspecific roles for HNF6 in pancreatic endocrine and ductal differentiation. Mech Dev 126: 958-973.

Zhou Q, Law AC, Rajagopal J, Anderson WJ, Gray PA, Melton DA. 2007. A multipotent progenitor domain guides pancreatic organogenesis. Dev Cell 13: 103-114.

Zhou Q, Brown J, Kanarek A, Rajagopal J, Melton DA. 2008. In vivo reprogramming of adult pancreatic exocrine cells to $\beta$-cells. Nature 455: 527-632. 


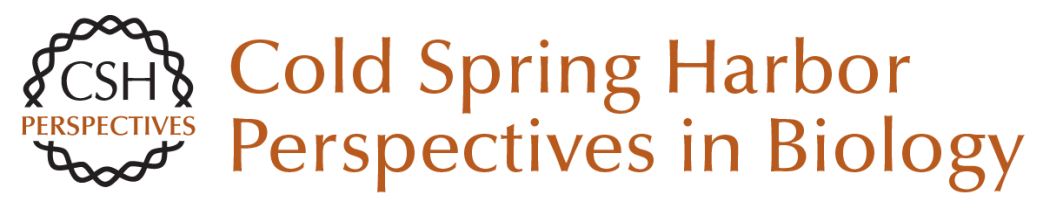

\section{Deconstructing Pancreas Developmental Biology}

Cecil M. Benitez, William R. Goodyer and Seung K. Kim

Cold Spring Harb Perspect Biol 2012; doi: 10.1101/cshperspect.a012401 originally published online May 15, 2012

\section{Subject Collection Mammalian Development}

The Dynamics of Morphogenesis in the Early Mouse Embryo

Jaime A. Rivera-Pérez and Anna-Katerina Hadjantonakis

microRNAs as Developmental Regulators Kathryn N. Ivey and Deepak Srivastava

Development of the Endochondral Skeleton Fanxin Long and David M. Ornitz

\section{Adipogenesis}

Kelesha Sarjeant and Jacqueline M. Stephens

Molecular Mechanisms of Inner Ear Development Doris K. Wu and Matthew W. Kelley

Polarity in Mammalian Epithelial Morphogenesis Julie Roignot, Xiao Peng and Keith Mostov

Eye Development and Retinogenesis

Whitney Heavner and Larysa Pevny

Primordial Germ Cells in Mice

Mitinori Saitou and Masashi Yamaji
Cell Division Modes and Cleavage Planes of

Neural Progenitors during Mammalian Cortical

Development

Fumio Matsuzaki and Atsunori Shitamukai

Blood and Lymphatic Vessel Formation

Victoria L. Bautch and Kathleen M. Caron

Transcriptional Networks in Liver and Intestinal

Development

Karyn L. Sheaffer and Klaus H. Kaestner

Pluripotency in the Embryo and in Culture Jennifer Nichols and Austin Smith

Signaling and Transcriptional Networks in Heart

Development and Regeneration

Benoit G. Bruneau

Signals and Switches in Mammalian Neural Crest

Cell Differentiation

Shachi Bhatt, Raul Diaz and Paul A. Trainor

Hematopoiesis

Michael A. Rieger and Timm Schroeder

Intercellular Interactions, Position, and Polarity in

Establishing Blastocyst Cell Lineages and

Embryonic Axes

Robert O. Stephenson, Janet Rossant and Patrick P.L. Tam

For additional articles in this collection, see http://cshperspectives.cshlp.org/cgi/collection/

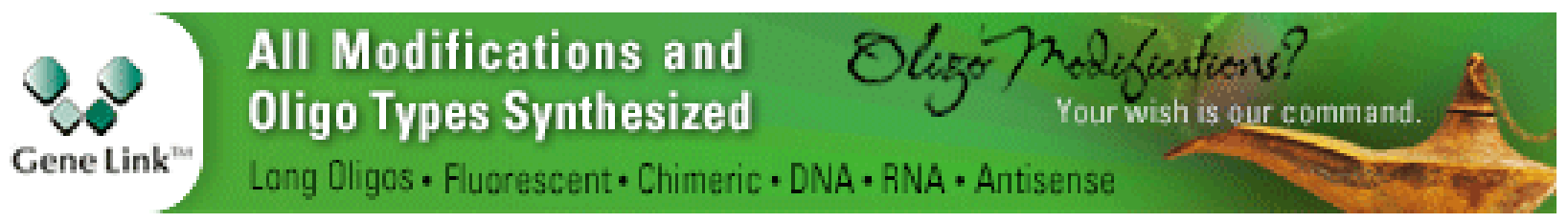

Copyright @ 2012 Cold Spring Harbor Laboratory Press; all rights reserved 